\author{
Marquette University \\ e-Publications@Marquette
}

$12-2005$

\title{
ATR-FTIR Spectroscopic Analysis of Sorption of Aqueous Analytes into Polymer Coatings Used with Guided SH-SAW Sensors
}

Yolanda K. Jones

Alcorn State University

Zhonghui Li

Marquette University

Michael M. Johnson

Marquette University

Fabien Josse

Marquette University, fabien.josse@marquette.edu

Jeanne Hossenlopp

Marquette University, jeanne.hossenlopp@marquette.edu

Follow this and additional works at: https://epublications.marquette.edu/chem_fac

Part of the Chemistry Commons, and the Electrical and Computer Engineering Commons

\section{Recommended Citation}

Jones, Yolanda K.; Li, Zhonghui; Johnson, Michael M.; Josse, Fabien; and Hossenlopp, Jeanne, "ATR-FTIR Spectroscopic Analysis of Sorption of Aqueous Analytes into Polymer Coatings Used with Guided SHSAW Sensors" (2005). Chemistry Faculty Research and Publications. 1.

https://epublications.marquette.edu/chem_fac/1 


\title{
ATR-FTIR Spectroscopic Analysis of Sorption of Aqueous Analytes into Polymer Coatings used with Guided SH-SAW Sensors
}

\author{
Yolanda K. Jones \\ Department of Chemistry, Marquette University \\ Milwaukee, WI \\ Zhonghui Li \\ Microsensor Research Laboratory and Department of Electrical \\ and Computer Engineering, Marquette University \\ Milwaukee, WI \\ Michael Johnson \\ Microsensor Research Laboratory and Department of Electrical \\ and Computer Engineering, Marquette University \\ Milwaukee, WI \\ Fabien Josse \\ Microsensor Research Laboratory and Department of Electrical \\ and Computer Engineering, Marquette University \\ Milwaukee, WI \\ Jeanne M. Hossenlopp \\ Department of Chemistry, Marquette University \\ Milwaukee, WI
}

IEEE Sensors Journal, Vol. 5, No. 6 (December 2005): pg. 1175-1184. DOI. This article is ( Institute of Electrical and Electronics Engineers (IEEE) and permission has been granted for this version to appear in e-Publications@Marquette. Institute of Electrical and Electronics Engineers (IEEE) does not grant permission for this article to be further copied/distributed or hosted elsewhere without the express permission from Institute of Electrical and Electronics Engineers (IEEE). 
Abstract: Attenuated total internal reflectance Fourier transform infrared (ATR-FTIR) spectroscopy was used for the investigation of sorption of aqueous solutions of analytes into polymer coatings. A series of simple model polymers: poly(dimethylsiloxane) (PDMS), poly(epichlorhydrin) (PECH), and poly(isobutylene) (PIB) films and analytes: aqueous solutions of ethylbenzene, xylenes, toluene, and nitrobenzene were used to evaluate the use of ATR-FTIR spectroscopy as a screening tool for sensor development. The ratios of integrated infrared absorption bands provided a simple and efficient method for predicting trends in partition coefficients. Responses of polymer-coated guided shear horizontal surface acoustic wave (SH-SAW) sensor platforms to the series of analytes, using polymer coatings with similar viscoelastic properties, were consistent with ATR-FTIR predictions. Guided SH-SAW sensor responses were linear in all cases with respect to analyte concentration in the tested range. Comparison of ATR-FTIR data with guided SH-SAW sensor data identifies cases where mass loading is not the dominant contribution to the response of the acoustic wave sensor. ATR-FTIR spectra of nitrobenzene, coupled with computational chemistry, provided additional insight into analyte/polymer interactions.

Keywords: Liquid Sensors, guided shear horizontal surface acoustic wave, attenuated total reflectance Fourier transform infrared spectroscopy

\section{Introduction}

Guided shear horizontal surface acoustic wave (guided SH-SAW) devices have been shown to be effective chemical and biochemical sensors in liquid environments [1]. One of the challenges in optimizing these devices for detection of aqueous analytes, including explosives, pesticide residues, and metabolites of chemical warfare agents, is the selection and/or development of coatings that are stable in water and which are also sensitive to the polar analytes common in these applications. The difference between gas and liquid sensing with respect to coating selection can be demonstrated by considering partition coefficients for sorption of an analyte from either the gas phase or from water into the polymer coating $[2,3]$.

The partition coefficient (or equilibrium constant) $\mathrm{K}$ represents the ratio of the analyte concentration in the polymer to the analyte concentration in gas or liquid phase in contact with the polymer-coated device, $C_{A}$. In the limit of only mass-loading contributions and/or for cases where viscoelastic contributions are low or negligible to mass

IEEE Sensors Journal, Vol. 5, No. 6 (December 2005): pg. 1175-1184. DOI. This article is @ Institute of Electrical and Electronics Engineers (IEEE) and permission has been granted for this version to appear in e-Publications@Marquette. Institute of Electrical and Electronics Engineers (IEEE) does not grant permission for this article to be further copied/distributed or hosted elsewhere without the express permission from Institute of Electrical and Electronics Engineers (IEEE) 
loading, the observed frequency shift, $\Delta_{\mathrm{fobs}}$, of a guided SH-SAW sensor exposed to an analyte can be related to $\mathrm{K}$ as well as the concentration of analyte, $\mathrm{C}_{\mathrm{A}}$, the frequency shift of the device due to the polymer layer, $\Delta \mathrm{f}_{\mathrm{s}}$, and the density of the polymer layer, $\rho_{\mathrm{s}}$, as shown in eq. (1) $[4,5]$.

$$
\Delta f_{o b s}=\frac{\Delta f_{s} C_{A} K}{\rho_{s}}
$$

The partition coefficient is related to the free energy of solvation, $\Delta G_{\text {solv }}$, as shown in eq. (2) where $T$ is the temperature in Kelvin and $R$ is the gas law constant.

$$
\Delta \mathrm{G}_{\mathrm{solv}}=-\mathrm{RT} \ln (\mathrm{K})
$$

$\mathrm{K}$ can be modeled using regression analysis of experimental data with the Linear Solvation Free Energy Relationship (LSFER) [2] shown in eq. (3).

$$
\log \mathrm{K}=c+r \mathrm{R}+s \Pi^{\mathrm{H}}+a \alpha^{\mathrm{H}}+b \beta^{\mathrm{H}}+l \log \mathrm{L}^{16}
$$

The first parameter in each term represents a polymer parameter: $c$ designates properties not included in other variables; $r$ is the regression coefficient which represents the tendency of the polymer to interact through nonbonding ( $n$ ) and $\pi$-bonding electron pairs; $a$ is the hydrogen bond basicity; $b$ is the hydrogen bond acidity; and $I$ represents the ability to distinguish between molecules in a homologous series. Parameters that are determined for specific analytes are $\mathrm{R}$, the polarizability contribution from $\mathrm{n}$ and $\pi$ electrons; $\Pi^{H}$, the dipolarity; $\alpha^{H}$, the hydrogen bond acidity; $\beta^{H}$, the hydrogen bond basicity; and $\mathrm{L}^{16}$, the gas-liquid partition coefficient of $\mathrm{n}$ hexadecane at $298 \mathrm{~K}$. The above modeling has been used extensively in the analysis of gas-phase sensors [2]. Partitioning of an analyte from water into a polymer coating can be estimated by determining the air/polymer partition coefficient, $\mathrm{K}_{\mathrm{a} \rightarrow \mathrm{p}}$, and the partition coefficient from air to water (i.e., the Henry's Law coefficient) $K_{a \rightarrow w}$, using IEEE Sensors Journal, Vol. 5, No. 6 (December 2005): pg. 1175-1184. DOI. This article is @ Institute of Electrical and Electronics Engineers (IEEE) and permission has been granted for this version to appear in e-Publications@Marquette. Institute of Electrical and Electronics Engineers (IEEE) does not grant permission for this article to be further copied/distributed or hosted elsewhere without the express permission from Institute of Electrical and Electronics Engineers (IEEE). 
literature data. The water to polymer partition coefficient, $\mathrm{K}_{\mathrm{w} \rightarrow \mathrm{p}}$ is the ratio $\mathrm{K}_{\mathrm{a} \rightarrow \mathrm{p}} / \mathrm{K}_{\mathrm{a} \rightarrow \mathrm{w}}[3]$.

In order to illustrate the importance of considering partition coefficients for aqueous sensing applications, $\mathrm{K}_{\mathrm{a} \rightarrow \mathrm{p}}$ and $\mathrm{K}_{\mathrm{w} \rightarrow \mathrm{p}}$ can be compared for a series of selected analytes (toluene, xylene, ethylbenzene, and nitrobenzene) with three different model polymer coatings, poly(dimethylsiloxane) (PDMS), poly(isobutylene) (PIB), and poly(epichlorhydrin). Structural formulas of the analytes and polymers are shown in Figure 1 . Note that in the partition coefficient analysis, as well as experimental work reported here, a mixture of all three xylene isomers (ortho-, meta-, and para-) will be used. Partition coefficients calculated using literature parameters [6 - 8] and the LSFER approach are shown in Table 1 . The partition coefficients for the nonpolar analytes (toluene, ethylbenzene, and xylenes) decrease by a factor of approximately four to five for detection of these species in water, as opposed to air, for each polymer. However, the partition coefficient for nitrobenzene decreases by a factor of 350 when going from gas-phase to aqueous phase detection, demonstrating that coatings that work well in gas sensing applications may be substantially less-sensitive for detecting polar analytes in aqueous environments. The challenges thus associated with identifying sensitive, water-stable coatings with the appropriate viscoelastic properties for use with SH-SAW devices, require development of efficient screening methodologies to aid in the selection of optimal coatings. Infrared (IR) spectroscopy is an excellent tool for this goal since spectral features can be used to identify the molecular species present in a sample, determine the concentration of a specific analyte given appropriate calibration, and also provide insight into the physical and chemical interactions between analytes and coatings.

The absorbance of infrared radiation for a sample as a function of infrared wavenumber $v\left(\mathrm{~cm}^{-1}\right)$ is determined from measurement of the incident IR intensity, $\mathrm{I}_{0}$, and transmitted intensity, I. Under conditions where the Beer-Lambert Law is valid, the absorbance, A, can be related to the extinction (absorption) coefficient of the sample, $\varepsilon(v)$, the concentration of the sample, $c$, and the path length that the infrared radiation passes through the sample, $I$, as shown in equation (4) [9].

IEEE Sensors Journal, Vol. 5, No. 6 (December 2005): pg. 1175-1184. DOI. This article is (C) Institute of Electrical and Electronics Engineers (IEEE) and permission has been granted for this version to appear in e-Publications@Marquette. Institute of Electrical and Electronics Engineers (IEEE) does not grant permission for this article to be further copied/distributed or hosted elsewhere without the express permission from Institute of Electrical and Electronics Engineers (IEEE) 


$$
\mathrm{A}=\log \left(\mathrm{I}_{0} / \mathrm{I}\right)=\varepsilon(v) \mathrm{c} l
$$

Traditional transmittance methods, however, are not appropriate for characterization of the partitioning of an analyte from an aqueous phase into a polymer. Attenuated total internal reflectance Fourier transform infrared spectroscopy (ATR-FTIR) has been shown to be a useful technique for analysis of aqueous solutions where the strong infrared absorbance of water precludes transmittance measurements [10] and has been utilized to analyze polymer films [11], water diffusion into polymer films [12], and analyte sorption into polymers [13-15]. A number of chemical sensors have been implemented for direct detection of analytes in both air and water based on ATR-FTIR strategies [16-18]. Infrared reflection methods have also been applied to provide insight into the interaction between gas-phase analytes and sensor coatings $[19,20]$.

A schematic representation of a horizontal ATR-FTIR element is shown in Figure 2. IR radiation is internally reflected through a $\mathrm{ZnSe}$ crystal at an angle, $\theta$, producing an evanescent wave at each reflection that penetrates slightly past the crystal surface. At each internal reflection the evanescent field interacts with any sample placed in contact with the ZnSe crystal. The depth, $d_{p}$, that the evanescent field penetrates into the sample at each reflection depends upon $\theta$ as well as the infrared wavelength in $\mathrm{ZnSe}, \lambda 1$, and the ratio of the refractive indices of the sample to ZnSe, n12 [21].

$$
d_{p}=\frac{\lambda_{1}}{2 \pi\left(\sin ^{2} \theta-n_{12}^{2}\right)^{1 / 2}}
$$

An absorption spectrum can be obtained by monitoring the intensity of reflected IR radiation and using a Beer-Lambert law expression similar to equation (4) where the path length $/$ is replaced by an effective thickness, $d_{\mathrm{e}}$, which is determined from the number of reflections and the wavelength-dependent $d_{p}[11,15]$. The depth of penetration of the evanescent field is 1-2 $\mu \mathrm{m}$ from the surface of the prism for the wavelength range of interest in this study. Use of a polymer film with a

IEEE Sensors Journal, Vol. 5, No. 6 (December 2005): pg. 1175-1184. DOI. This article is @ Institute of Electrical and Electronics Engineers (IEEE) and permission has been granted for this version to appear in e-Publications@Marquette. Institute of Electrical and Electronics Engineers (IEEE) does not grant permission for this article to be further copied/distributed or hosted elsewhere without the express permission from Institute of Electrical and Electronics Engineers (IEEE). 
thickness which is significantly greater than $d_{p}$, as shown schematically in Figure 2, insures that only those analytes that partition from the aqueous phase into the polymer coating and diffuse to within the $\sim 1$ $2 \mu \mathrm{m}$ distance from the surface of the prism will be detected.

While ATR-FTIR spectra can exhibit shifts in peak position and/or distortion of absorption band shapes when compared with transmission measurements, particularly in the case of strong absorbances where dispersion effects can be significant [11], the use of ratios of integrated absorption bands has been shown to be an appropriate strategy for making quantitative comparisons [15, 22]. The integrated band intensity is obtained from an assigned analyte transition with the lower and upper limits of the absorption band, in units of $\mathrm{cm}^{-1}$, designated as $v_{\text {lower }}$ and $v_{\text {upper. }}$. The extent of partitioning of an analyte from water into a polymer coating, is thus determined from the ratio, $\mathrm{R}_{\mathrm{IR}}$, of the integrated band intensity of an analyte vibrational band when sorbed into the polymer to that of the same analyte band in water as shown in equation (6).

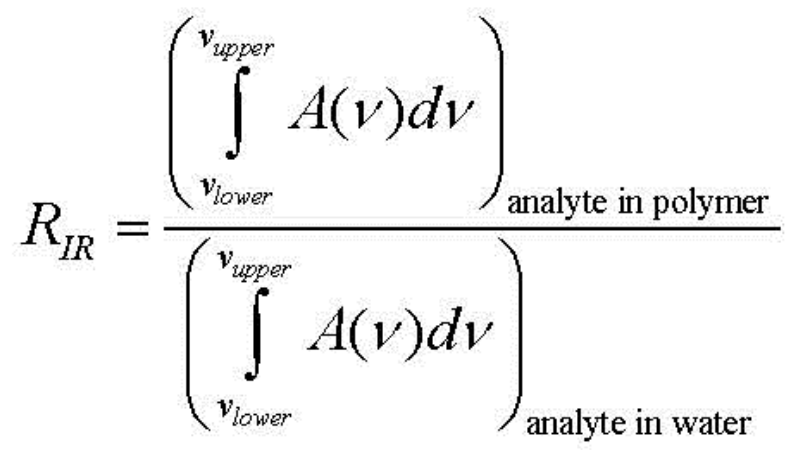

The numerator of equation (6) is determined from data obtained using the experimental configuration shown in Figure 2 and the denominator is obtained from the spectrum of the aqueous analyte solution on a bare prism (i.e. with no polymer coating). Under the experimental conditions in this study, $\mathrm{R}_{\mathrm{IR}}$ provides estimates for partitioning that are proportional, although not identitical, to $\mathrm{K}_{\mathrm{w} \rightarrow \mathrm{p}}$. This provides a convenient means for preliminary screening of new sensor coatings. In addition, comparison of shifts in position of analyte peaks when in different environments with results of computational chemistry

IEEE Sensors Journal, Vol. 5, No. 6 (December 2005): pg. 1175-1184. DOI. This article is @ Institute of Electrical and Electronics Engineers (IEEE) and permission has been granted for this version to appear in e-Publications@Marquette. Institute of Electrical and Electronics Engineers (IEEE) does not grant permission for this article to be further copied/distributed or hosted elsewhere without the express permission from Institute of Electrical and Electronics Engineers (IEEE). 
analysis provides insight into the dominant modes of interaction between analytes and coatings. Comparison of $\mathrm{R}_{\mathrm{IR}}$ and $\mathrm{K}_{\mathrm{w} \rightarrow \mathrm{p}}$ with guided SH-SAW sensor responses demonstrates the importance of also considering viscoelastic effects when designing coatings.

\section{Experimental}

All materials and reagents were supplied by Aldrich unless otherwise specified and were used as supplied without any further purification: vinyl terminated poly(dimethylsiloxane) (viscosity 1000 cSt), poly(methylhydrosiloxane), platinum carbonyl complex (Gelest, 3-3.5\% platinum concentration in vinyl terminated PDMS), dichloromethane (99.6\%), poly(methylmethacrylate), 2ethoxyethylacetate, poly(isobutylene), poly(epichlorhydrin), chloroform (99.8\%), toluene (99.5\%), ethylbenzene (99\%), xylenes (mixed isomers, 98.5\%), nitrobenzene (99\%). Aqueous solutions of analytes were prepared using in Milli-Q deionized water (13-14 MOhm $\mathrm{cm}$ ).

Poly(dimethylsiloxane) (PDMS) was crosslinked via a hydrosilylation reaction $[23,24]$ to prepare a water stable elastomeric film. $0.05 \mathrm{~g}$ poly(methylhydrosiloxane) and $3.1 \mathrm{~g}$ vinyl terminated poly(dimethylsiloxane) were added, while stirring, to dichloromethane to obtain 5 and 12 wt\% solutions. After a homogenous composition was obtained, 4 drops of platinum carbonyl complex were added and solutions were stored at room temperature until use. Poly(isobutylene) (PIB) and poly(epichlorhydrin) (PECH) solutions were prepared by dissolving the appropriate amount of each polymer in chloroform to make 2 wt\% and 4 wt\% solutions respectively.

Attenuated total reflectance Fourier transform infrared spectroscopy (ATR-FTIR) was performed using a Nicolet Magna 560 Spectrometer equipped with a Pike horizontal ATR accessory with a covered sample trough. The reflectance element was a $\theta=45^{\circ} \mathrm{ZnSe}$ crystal with ten internal reflections. The ATR element was covered with sufficient volumes of each polymer solution to produce $50 \mu \mathrm{m}$ thick films after curing. The solvent was evaporated at room temperature producing a uniform film. In order to obtain a specific film thickness, the required mass of solid polymer was obtained by multiplying the IEEE Sensors Journal, Vol. 5, No. 6 (December 2005): pg. 1175-1184. DOI. This article is @ Institute of Electrical and Electronics Engineers (IEEE) and permission has been granted for this version to appear in e-Publications@Marquette. Institute of Electrical and Electronics Engineers (IEEE) does not grant permission for this article to be further copied/distributed or hosted elsewhere without the express permission from Institute of Electrical and Electronics Engineers (IEEE). 
weight percent of the polymer in solution by the density of the polymer solution and the volume of the solution used on the prism. This quantity was divided by the product of the density of the solid polymer and area of the prism surface to obtain the film thickness. PDMS films were cured at $115^{\circ} \mathrm{C}$ for 15 minutes. The PIB and PECH films were not cured after solvent evaporation.

ATR-FTIR spectra were obtained for the polymers (with and without exposure to water) and for the polymers after exposure to $2.00 \mathrm{ml}$ of ethylbenzene $(1.3 \mathrm{mM})$, xylenes $(1.7 \mathrm{mM})$, toluene $(5.9$ $\mathrm{mM})$, and nitrobenzene $(13.0 \mathrm{mM})$ saturated solutions [25]. The system was allowed to sit for five minutes after exposure of the polymer to analyte solutions; this time was found to be sufficient for equilibration with respect to analyte diffusion into the coating, with spectra remaining constant. Spectra were also collected for $2.00 \mathrm{ml}$ aliquots of the analyte solutions on the bare prism. All spectra were obtained using $1 \mathrm{~cm}^{-1}$ spectral resolution, averaging a minimum of 160 scans. Spectra were corrected for wavelength dependent differences in penetration depth of the evanescent wave.

Sensing measurements were made using guided $\mathrm{SH}-\mathrm{SAW}$ devices with dual delay line configuration on $36^{\circ} \mathrm{YX}-\mathrm{LiTaO}_{3}$ substrates. One delay line is used as the sensing line and the other serves as the reference line. The devices were designed and fabricated with 10/90 $\mathrm{nm}$ thick $\mathrm{Cr} / \mathrm{Au}$ interdigital transducers (IDTs) having a periodicity of $40 \mu \mathrm{m}$, which corresponds to an operating frequency of approximately $103 \mathrm{MHz}$ for the bare devices. The use of the dual delay lines makes secondary interaction controls such as temperature control unnecessary. A metalized delay path between input and output IDTs was used to eliminate acousto-electric interactions with the load. The PDMS, PECH, and PIB solutions were spin coated onto the sensing lines in order to obtain uniform $0.5-0.8 \mu \mathrm{m}$ thick films. Thickness calibration was performed using polymer films coated onto thicknessshear-mode (TSM) resonators using identical coating conditions as for the SH-SAW devices. The Sauerbrey equation [26] was used to obtain the film thickness from the frequency shift induced by deposition of the polymer onto the bare TSM. Care was taken to ensure that the film thicknesses were in the regime where the Sauerbrey equation is valid.

IEEE Sensors Journal, Vol. 5, No. 6 (December 2005): pg. 1175-1184. DOI. This article is ( Institute of Electrical and Electronics Engineers (IEEE) and permission has been granted for this version to appear in e-Publications@Marquette. Institute of Electrical and Electronics Engineers (IEEE) does not grant permission for this article to be further copied/distributed or hosted elsewhere without the express permission from Institute of Electrical and Electronics Engineers (IEEE). 
The PDMS film was cured for 20 minutes at $120^{\circ} \mathrm{C}$. The reference line of each device was previously coated with a $0.8 \mu \mathrm{m}$ or $0.5 \mu \mathrm{m}$ thick poly(methylmethacrylate) (PMMA) film to correspond to film thickness of the polymer coated on the sensing line. The PMMA films were obtained by spin coating PMMA in 2-ethoxyethylacetate (caution: reproductive hazard) and curing at $180^{\circ} \mathrm{C}$ for 2 hours. The PMMA waveguide provides a dielectric shield/passivation on metallic electrodes and transducer elements, therefore reducing the extent of the electric field and also allows for trapping of the acoustic wave at the device surface. The performance of PMMA for these purposes in liquid sensing applications has been extensively evaluated in our previous work [1].

The polymer-coated devices were exposed to aqueous samples of the analytes in Milli-Q deionized water. A specially designed flowthrough cell was used to expose each guided SHSAW delay line to the chemical environment Deionized water was initially pumped through the cell at a rate of $0.30 \mathrm{~mL} / \mathrm{min}$, after which each analyte solution was introduced. Between exposures to analyte solutions, the devices were flushed with deionized water to return the response to the baseline. The PECH and PDMS coated sensors were exposed to $50 \mathrm{ppm}$ ( $\sim 0.5 \mathrm{mM})$ samples of toluene, ethylbenzene, xylenes, and nitrobenzene. To study concentration dependence using the PDMS coated sensor, the device was exposed to five concentrations of ethylbenzene ranging from 25-125 ppm ( 0.2-1 mM) and four concentrations of nitrobenzene ranging from 200-800 ppm ( 1.6-6.3 $\mathrm{mM})$. The PIB coated device was exposed to six samples of each analyte ranging in concentration from 10-60 ppm ( 0.1-0.6 mM).

A network analyzer (Agilent 8753ES) with a switch/control unit (Agilent 3499A) was used for the sensing experiments to allow continuous monitoring of the sensing and reference channels. The use of the switch control unit guarantees that both devices are measured under the same conditions. A PC-based HP VEE control program was used to collect the sensor data insertion loss and phase/frequency measurement simultaneously for both the reference and sensing lines every 30 seconds. The liquid sample cell and measurement collection protocol have been described elsewhere [1].

IEEE Sensors Journal, Vol. 5, No. 6 (December 2005): pg. 1175-1184. DOI. This article is @ Institute of Electrical and Electronics Engineers (IEEE) and permission has been granted for this version to appear in e-Publications@Marquette. Institute of Electrical and Electronics Engineers (IEEE) does not grant permission for this article to be further copied/distributed or hosted elsewhere without the express permission from Institute of Electrical and Electronics Engineers (IEEE) 
NOT THE PUBLISHED VERSION; this is the author's final, peer-reviewed manuscript. The published version may be accessed by following the link in the citation at the bottom of the page.

\section{Results and Discussion}

For the ATR-FTIR experimental configuration used in this work, the depth of penetration, $d_{p}$, of the infrared radiation ranges from 1-2 $\mu \mathrm{m}$. Since the polymer films are $50 \mu \mathrm{m}$ thick, only those analytes that diffuse through the polymer to within 1-2 $\mu \mathrm{m}$ of the prism surface will be detected. The tendency for a given analyte to partition from the aqueous phase into the polymer can thus be evaluated from the integrated intensities of infrared bands using equation (6), where the area of a peak for the analyte in the polymer is divided by the area for the same characteristic analyte peak in aqueous solution. Selected portions of typical ATR-FTIR spectra where analyte features can be observed without interference from the polymer spectrum are shown in Figures 3 and 4 for PDMS exposed to aqueous solutions of ethylbenzene and nitrobenzene, respectively. Spectra have been offset for clarity but have not been otherwise scaled. Polymer spectral features were not changed by exposure to the analyte solutions.

Characterization of ethylbenzene partitioning utilized the spectral features found at 1500 and $1450 \mathrm{~cm}^{-1}$ that have previously been assigned as the $19 a$ and $19 b$ ring modes [27]. No significant change in peak position for these modes was observed in the spectra obtained for pure ethylbenzene, aqueous ethylbenzene, and ethylbenzene partitioned into the polymer. There are, however, significant changes in relative intensity of these peaks. As expected, the peak intensities decreased when the pure ethylbenzene sample was replaced by the saturated aqueous solution where a lower analyte concentration was in contact with the prism surface. However, after partitioning into the polymer, the ethylbenzene peak intensities appear to increase relative to the aqueous sample, as expected from the large partition coefficient for water to PDMS partitioning listed in Table 1 $(\mathrm{Kw} \rightarrow \mathrm{p}=772)$. Qualitatively similar results were obtained for ethylbenzene partitioning into PIB and PECH as well as for toluene and xylenes partitioning into the three polymers.

Nitrobenzene partitioning, see Figure 4, was characterized using the asymmetric $\mathrm{NO}_{2}$ stretching mode found at $\sim 1530 \mathrm{~cm}^{-1}$ and the symmetric $\mathrm{NO}_{2}$ stretching mode found at $\sim 1350 \mathrm{~cm}^{-1}$ [28]. In aqueous solution these two bands were found to increase in height and become

IEEE Sensors Journal, Vol. 5, No. 6 (December 2005): pg. 1175-1184. DOI. This article is @ Institute of Electrical and Electronics Engineers (IEEE) and permission has been granted for this version to appear in e-Publications@Marquette. Institute of Electrical and Electronics Engineers (IEEE) does not grant permission for this article to be further copied/distributed or hosted elsewhere without the express permission from Institute of Electrical and Electronics Engineers (IEEE). 
sharper when compared with the neat nitrobenzene spectrum. After partitioning into the polymer, the peaks decreased markedly in intensity when compared with the aqueous solution spectrum. This trend is qualitatively consistent with $\mathrm{Kw} \rightarrow \mathrm{p}=1.5$ for nitrobenzene partitioning into PDMS.

The integrated intensities were determined for analyte infrared bands that were selected from spectral regions with minimal interference from water or polymer features as shown in Figures 3 and 4. $R_{I R}$ values were obtained for each analyte in each polymer by averaging the results obtained from two different vibrational bands and then compared with the calculated $\mathrm{Kw} \rightarrow \mathrm{p}$ values. The resulting trends in $\mathrm{R}_{\mathrm{IR}}$ are consistent with those listed in Table 1 for $\mathrm{Kw} \rightarrow \mathrm{p}$ for each polymer/analyte pair: ethylbenzene $\geq$ xylenes $>$ toluene $>>$ nitrobenzene.

In order to compare the results for trends in partitioning obtained from $\mathrm{R}_{\mathrm{IR}}$ with sensor behavior, the sensing lines of guided SH-SAW devices were coated with PDMS, PECH, or PIB, and exposed to varying concentrations of the aqueous solutions of analytes. Typical sensor response data is shown in Figures 5-8. Figure 5 shows the observed frequency shift for a $0.8 \mu \mathrm{m}$ PIB coated sensor to 10-60 ppm ( 0.1-0.6 mM) concentrations of xylenes. The response of the sensor is returned to the baseline upon exposure to deionized water, demonstrating reversibility. The observed frequency shifts are linear with respect to concentration as shown in Figure 6 for the ethylbenzene, xylenes and toluene; the response to nitrobenzene is negligible in this concentration range. Similar results are obtained using a PECH-coated device.

Higher concentrations of nitrobenzene were necessary in order to observe sensor response to nitrobenzene; a typical example is shown for a PDMS-coated device exposed to 200-800 ppm ( 1.6-6.3 $\mathrm{mM}$ ) of nitrobenzene in Figure 7. However, in contrast to the PIB- and $\mathrm{PECH}$-coated devices, use of a PDMS coating leads to a reversible increase in frequency when exposed to the nonpolar analytes: toluene, ethyl benzene, and xylenes. This can be seen in the data shown in Figure 8 for exposure to 25-125 ppm ( 0.2-1 mM) of ethylbenzene. This anomalous behavior in detection of nonpolar analytes was

IEEE Sensors Journal, Vol. 5, No. 6 (December 2005): pg. 1175-1184. DOI. This article is @ Institute of Electrical and Electronics Engineers (IEEE) and permission has been granted for this version to appear in e-Publications@Marquette. Institute of Electrical and Electronics Engineers (IEEE) does not grant permission for this article to be further copied/distributed or hosted elsewhere without the express permission from Institute of Electrical and Electronics Engineers (IEEE). 
observed even when varying the film thickness and curing conditions. We also note that the observed frequency decreases upon exposure of the device to pure water. Regardless of the sign of the frequency shift, the response is linear in the measured concentration range, within the limits of experimental uncertainty.

The contribution of modulus effects to SAW gas sensor response is well documented, demonstrating that the simple mass-loading model shown in eq. (1) is often insufficient for predicting the magnitude of sensor response [29-33]. Positive frequency shifts have also been observed for SAW devices coated with PDMS films and exposed to selected gas phase analytes [34-36]. A similar, analytedependent effect has also been reported for $97 \mathrm{MHz}$ SAW devices coated with polybutadiene/polystyrene films [37]. Observed frequency shifts for SAWs coated with lightly crosslinked polymers, where the bulk modulus is large compared with the shear modulus, can be characterized in terms of the relative contributions of mass loading and viscoelastic changes by $[34,37]$ :

$$
\frac{\Delta f}{f_{0}}=-c_{1} \omega \times \Delta(h \rho)-c_{2} \omega h \times \Delta\left[\frac{\mu(\omega \tau)^{2}}{1+(\omega \tau)^{2}}\right]
$$

where $c_{1}$ and $c_{2}$ represent substrate-dependent parameters, $\omega$ is the SAW angular frequency, $h$ is the film thickness, $\rho$ is the film mass density, $\mu$ is the polymer dynamic shear modulus, and $T$ is the shear relaxation time of the polymer. The first term in equation (7) represents the massloading contribution that was shown in equation (2). The second term represents the viscoelastic contribution which can have either a net positive or a negative value depending on the value of $\omega$ T. The overall sign of the observed frequency shift will be negative where $\omega \mathrm{T}>>1$ and positive where $\omega \mathrm{T}<<1$ [34]. In the region where $\omega \mathrm{T} \approx 1$, significant changes in the polymer relaxation time due to interaction of the coating with the analyte (as well as due to temperature changes) can lead to differences in the sign of the observed frequency shifts. The relationship between device angular frequency and the polymer shear relaxation time thus controls the sign of the observed frequency shift. The relaxation time can further be

IEEE Sensors Journal, Vol. 5, No. 6 (December 2005): pg. 1175-1184. DOI. This article is @ Institute of Electrical and Electronics Engineers (IEEE) and permission has been granted for this version to appear in e-Publications@Marquette. Institute of Electrical and Electronics Engineers (IEEE) does not grant permission for this article to be further copied/distributed or hosted elsewhere without the express permission from Institute of Electrical and Electronics Engineers (IEEE). 
related to the shear modulus, $\mu$, and shear viscosity, $\eta$, of the polymer: $\mathrm{T}=\eta / \mu[37]$.

For a SAW device operating at $158 \mathrm{MHz}$, $\omega$ T was reported to be 0.7 for PDMS [34]. Assuming similar coating properties, with the 103$\mathrm{MHz}$ devices used in this work, $\omega \mathrm{T}$ is expected to $\sim 0.5$ for PDMS. The observed frequency shifts are consistent with significant perturbations in $\mathrm{T}$ due to sorption of analytes into the coating. Martin and Frye [37] attribute temperature- and analyte-dependent changes in relaxation time for a polybutadiene/polystyrene block copolymer primarily to changes in dynamic viscosity, a plasticization effect, while Ahuja et al. [34] suggest that PDMS relaxation times are controlled by activation barriers for conformational changes in the polymer backbone. Further work is necessary to evaluate these, and other, possibilities in our system; experiments are currently in progress in our laboratory to evaluate the effects of analyte sorption on polymer shear modulus. In future studies, the ATRFTIR technique will also be extended to provide additional information on issues such as the mechanism of water diffusion and analyte sorption into the polymer, and swelling changes in the polymer which may be related to swelling-induced modulus changes in the guided SH-SAW sensor responses.

Given that the frequency shifts obtained with the PDMS-coated devices were found to be linear with respect to analyte concentration (Fig. 9), the magnitude of $\Delta \mathrm{f}$ will be used for comparison between the different coatings. The values of $R_{I R},|\Delta f|$, and $K w \rightarrow p$ are shown in Figure 10 for detection of xylenes. The $\mathrm{R}_{\mathrm{IR}}$ values match the general trend in partition coefficients, PDMS $>\mathrm{PECH}>\mathrm{PIB}$, but the absolute magnitude of the guided $\mathrm{SH}-\mathrm{SAW}$ response is $\mathrm{PECH}>\mathrm{PIB}>\mathrm{PDMS}$ for a $0.5 \mathrm{mM}$ solution of xylenes. The significantly decreased guided $\mathrm{SH}-\mathrm{SAW}$ response for the PDMS coated device is consistent with equation (7). The first term in eq. (7), the mass loading contribution, is always negative. As discussed previously, the positive frequency shifts observed with the PDMS coated device for nonpolar analytes such as xylenes indicates a significant and positive contribution from the second term (i.e. $\omega \mathrm{T}<<1$ ). The two terms in eq. (7) therefore offset each other somewhat in this case, leading to the decreased sensitivity when compared to the other two coatings.

IEEE Sensors Journal, Vol. 5, No. 6 (December 2005): pg. 1175-1184. DOI. This article is @ Institute of Electrical and Electronics Engineers (IEEE) and permission has been granted for this version to appear in e-Publications@Marquette. Institute of Electrical and Electronics Engineers (IEEE) does not grant permission for this article to be further copied/distributed or hosted elsewhere without the express permission from Institute of Electrical and Electronics Engineers (IEEE). 
Despite the anomalous behavior for the PDMS-coated guided $\mathrm{SH}-\mathrm{SAW}$, quantitative comparisons between $\mathrm{R}_{\mathrm{IR}}$, the absolute value of the guided $\mathrm{SH}-\mathrm{SAW}$ sensor response $(|\Delta \mathrm{f}|)$, and predicted $\mathrm{KW} \rightarrow \mathrm{p}$ can be made for sorption of the analytes in the model series since sensor responses are linear with respect to concentration over the range examined here. In Figure 11, data are shown for each coating with respect to the series of analytes. The three parameters, $\mathrm{R}_{\mathrm{IR}}$, $|\Delta \mathrm{f}|$ for exposure of the device to a flowing $50 \mathrm{ppm}(0.5 \mathrm{mM})$ solution of each analyte, and $\mathrm{Kw} \rightarrow \mathrm{p}$ are normalized to the respective value for toluene in order to facilitate comparison. In the case of the PDMS coating, the trends in $R_{I R}$ and $|\Delta f|$ match the trend in predicted partition coefficients for the four analytes. When $\mathrm{PECH}$ is used as the coating, the ATR-FTIR data have a reversed trend with respect to the guided SH-SAW response and partition coefficient when comparing ethyl benzene and xylenes but the relative response with respect to the other analytes is consistent. Similar behavior is observed for PIB where the overall trends are consistent but where the response for ethyl benzene and xylenes is reversed for the ATR-FTIR data compared with guided SH-SAW response and predicted partition coefficients. Typical uncertainties in $\mathrm{R}_{\mathrm{IR}}$ based on averaging two measurements are found to be approximately $15 \%$ and therefore the difficulty in discriminating between ethyl benzene and xylenes, where the partition coefficients differ by less than $5 \%$, is not surprising.

Minor differences between $\mathrm{R}_{\mathrm{IR}}$ and $\mathrm{KW} \rightarrow \mathrm{p}$ may also arise since LSFER parameters are determined in the limit of infinite dilution and also since a static ATR sample holder was used here, leading to decreases in concentration of analyte in the aqueous phase as the analyte partitions into the polymer. In addition, it is important to note that potential differences in extinction (absorption) coefficient $\varepsilon(v)$ for analytes in the different environments were not included in our analysis. Correction for these effects would be necessary if discrimination between similar partition coefficients was necessary. However, as implemented here, the ATRFTIR method is a simple and efficient screening tool for evaluating overall trends in partition coefficients for a given coating with respect to series of analytes. The ATR-FTIR data and partition coefficients are useful as predictors of the guided SH-SAW frequency response to a series of analytes when using a single coating. The contribution of viscoelastic effects to guided

IEEE Sensors Journal, Vol. 5, No. 6 (December 2005): pg. 1175-1184. DOI. This article is @ Institute of Electrical and Electronics Engineers (IEEE) and permission has been granted for this version to appear in e-Publications@Marquette. Institute of Electrical and Electronics Engineers (IEEE) does not grant permission for this article to be further copied/distributed or hosted elsewhere without the express permission from Institute of Electrical and Electronics Engineers (IEEE) 
SH-SAW sensor response must also be considered, however, when comparing different coatings.

The fact that the polar analyte, nitrobenzene, leads to negative frequency shifts while the nonpolar analytes lead to positive frequency shifts while maintaining a linear concentration dependence profile also suggests that PDMS is a good candidate for use in a sensor array due to the differential response. Investigation of the response to additional analytes is needed to characterize the source of the apparent changes in polymer relaxation times with exposure to polar versus nonpolar analytes.

In addition to its utility for screening the trends of analyte partitioning into a coating, the ATR-FTIR data can also be used to provide insight into polymer/analyte interactions. This can be particularly useful in systematic efforts to design new coatings, where LSFER data may not be available. The position of the peak of an analyte infrared absorption band can shift due to the changes in the surrounding medium. Computational chemistry can be used to assist in interpreting the source of the observed infrared spectral shifts. One possible effect is that the spectral shifts are due to changes in the dielectric constant of the surrounding medium [38]. This can be considered a nonspecific interaction that can be modeled by treating the surrounding medium as a bulk dielectric. In addition, specific intermolecular interactions such as hydrogen bonding can also cause shifts in infrared spectral positions. Strong intermolecular attraction between analyte and coating will be associated with higher partition coefficients. The computational studies discussed below examine the role of nonspecific (bulk dielectric) and specific intermolecular interactions on the nitrobenzene infrared spectrum. The intermolecular interactions identified via computational analysis are also compared with LSFER data for these model systems.

The position of the nitrobenzene $\mathrm{NO}_{2}$ asymmetric and symmetric stretching modes observed in the ATR-FTIR spectra (Figure 4) are found to shift to higher $\mathrm{cm}^{-1}$ when the analyte partitions from water into any of three polymer coatings used in this study. Distortion due to dispersion effects in the strong absorption bands observed for the aqueous sample may contribute to this shift; however the change in

IEEE Sensors Journal, Vol. 5, No. 6 (December 2005): pg. 1175-1184. DOI. This article is @ Institute of Electrical and Electronics Engineers (IEEE) and permission has been granted for this version to appear in e-Publications@Marquette. Institute of Electrical and Electronics Engineers (IEEE) does not grant permission for this article to be further copied/distributed or hosted elsewhere without the express permission from Institute of Electrical and Electronics Engineers (IEEE). 
the local environment of the nitrobenzene molecules is expected to play a major role. The computational analysis presented here will focus on the shift in the asymmetric stretching mode, observed at $1518 \mathrm{~cm}^{-1}$ for nitrobenzene in water. All calculations were carried out using Gaussian-98W [39].

For polar analytes, the Onsager Self Consistent Reaction Field (SCRF) model can be used to determine the effect of solvent/polymer dielectric on the position of analyte vibrational modes [38, 40]. To perform this calculation, the gas phase geometry of nitrobenzene was first optimized using density functional theory with the B3LYP functional [41] and 6-311++G(d,p) basis set [42], using tight convergence criteria [39]. Onsager SCRF calculations were then performed at the B3LYP/6-311++G(d,p) level, using the molecular volume obtained in the gas phase calculation and dielectric constants of 78.54 and 2.80 for water and PDMS, respectively [43]. Vibrational frequency calculations were performed for each optimized structure and the results are summarized in Table 2 for the NO2 asymmetric stretching mode. As expected [44], the calculated frequencies deviate from experimental frequencies and a scaling factor of 0.98 was determined by comparing gas-phase experimental [28] and computational data for the vibrational mode of interest here. This scaling factor was then used to correct the rest of the computed vibrational frequencies; both unscaled and scaled data are shown in Table 2.

The scaled vibrational frequencies obtained from the B3LYP/6$311++G(d, p)$ Onsager SCRF calculation show reasonable agreement for the nitrobenzene NO2 asymmetric stretching mode in water and in PDMS; clearly the surrounding dielectric plays an important role in determining peak positions in this system. However, a more extensive joint experimental/computational study of solvent effects on infrared spectra of nitrobenzene and other nitroaromatic compounds, that will be published elsewhere, indicates that the Onsager model is insufficient for predicting vibrational frequency shifts in a wider range of solvents and that there also are nitrobenzene mode-dependent behaviors observed within a given solvent that are not consistent with the Onsager results. Specific intermolecular interactions between the

IEEE Sensors Journal, Vol. 5, No. 6 (December 2005): pg. 1175-1184. DOI. This article is @ Institute of Electrical and Electronics Engineers (IEEE) and permission has been granted for this version to appear in e-Publications@Marquette. Institute of Electrical and Electronics Engineers (IEEE) does not grant permission for this article to be further copied/distributed or hosted elsewhere without the express permission from Institute of Electrical and Electronics Engineers (IEEE). 
analyte and solvent/polymer functional groups must therefore also be considered.

The nature of these specific interactions was evaluated using a model system where the structure of a nitrobenzene molecule is optimized in the presence of an oligomeric unit of the polymer structure of PIB, PECH, and PDMS. These calculations were performed using the PM3 semi-empirical method [45] due to the size of the model system. In each case, the initial (preoptimized) geometry was constructed with the ONO moiety pointing toward the polymer chain. Calculations were also performed for a complex of nitrobenzene with one water molecule. Vibrational frequencies were computed from the equilibrium geometries and the values for the nitrobenzene $\mathrm{NO}_{2}$ asymmetric stretching mode are listed in Table 2. A scaling factor of 0.81 was used for the PM3 results.

The scaled vibrational frequencies from the PM3 calculation are qualitatively consistent with the shift to higher $\mathrm{cm}^{-1}$ observed when nitrobenzene partitions from water into the polymer coatings but this simple model system does not exactly reproduce experimental data, particularly when comparing PDMS with PIB. This is to be expected since the model system has a truncated polymer structure that will not represent the analyte surrounded by polymer and the observed spectral shifts are within the uncertainty of the calculations. However, the optimized geometries, shown in Figure 12, are useful for identifying the nature of the intermolecular interactions. In the case of nitrobenzene interacting with PIB, examination of LSFER parameters [6-8] indicates that dispersion and cavity effects will dominate that partition coefficient. The PM3 optimized geometry (Fig. 12A) is consistent with this analysis, with the aromatic portion of the analyte closest to the polymer chain segment which orients itself away from the nitrobenzene molecule, suggesting non-specific interactions are dominant in this case. The LSFER parameters for PECH interacting with nitrobenzene suggest that while dispersion and cavity effects will be the strongest contributors to the partition coefficient, dipolarity, and to a lesser extent hydrogen bonding interactions via the $b \beta^{H}$ term, also playing a role. The nitrobenzene/PECH optimized structure (Fig. 12B) shows short range interactions indicative of dipolar and hydrogen bond interactions between the $\mathrm{NO}_{2}$ group and the $\mathrm{Cl}-\mathrm{C}-\mathrm{H}$ segment of the

IEEE Sensors Journal, Vol. 5, No. 6 (December 2005): pg. 1175-1184. DOI. This article is @ Institute of Electrical and Electronics Engineers (IEEE) and permission has been granted for this version to appear in e-Publications@Marquette. Institute of Electrical and Electronics Engineers (IEEE) does not grant permission for this article to be further copied/distributed or hosted elsewhere without the express permission from Institute of Electrical and Electronics Engineers (IEEE). 
polymer chain. Based on LSFER analysis, PDMS is expected to behave similarly to PECH. The optimized structure in Fig. 12C, where the polymer chain is oriented along the nitrobenzene molecule, is consistent with dipolar interactions. Finally, the nitrobenzene/water complex (Fig. 12D) clearly shows hydrogen bonding.

We note that in studies of solute orientational relaxation in PDMS melts, [46] strong intermolecular interaction between a polar solute and the PDMS backbone resulted in significantly larger activation energies for solute reorientation when compared with a nonpolar solute. In addition, the intermolecular interaction was also postulated to perturb the physical properties of PDMS by impeding rotation about the $\mathrm{Si}-\mathrm{O}$ bond. The structure shown in Fig. $12 \mathrm{C}$ is consistent with nitrobenzene interaction with the PDMS polymer backbone, which could in turn perturb conformational relaxation processes [34] differently from nonpolar solutes which have minimal dipolar interactions. Molecular dynamics simulations would be useful in more fully characterizing the effects of analyte/polymer interactions in this system [47].

ATR-FTIR spectroscopy can thus be used to quickly estimate partition coefficients and, when coupled with computational chemistry studies, can also provide insight into the nature of analyte/coating interactions.

\section{Conclusions}

ATR-FTIR spectroscopy has shown to be a simple, efficient means for first order analysis of the partitioning of a series of model analytes from aqueous solution into polymer coatings. The ratios of integrated infrared absorption bands are proportional to literature partition coefficients, within the limits of experimental uncertainty. Trends in magnitude of response of a polymer-coated guided SH-SAW sensor platform, when exposed to a series of different analytes, can be determined using the ATR-FTIR screening approach. The relative sensitivity toward a given analyte for guided SH-SAW sensor platforms coated with different polymers can also be predicted for polymers with similar viscoelastic properties such as PECH and PIB. However, the potential contribution of viscoelastic effects to guided SH-SAW

IEEE Sensors Journal, Vol. 5, No. 6 (December 2005): pg. 1175-1184. DOI. This article is @ Institute of Electrical and Electronics Engineers (IEEE) and permission has been granted for this version to appear in e-Publications@Marquette. Institute of Electrical and Electronics Engineers (IEEE) does not grant permission for this article to be further copied/distributed or hosted elsewhere without the express permission from Institute of Electrical and Electronics Engineers (IEEE). 
responses in liquid sensing requires further examination, particularly in the case of PDMS-coated sensors. The ATR-FTIR data can also be used, in combination with computational chemistry, to provide fundamental insight into the interaction of nitrobenzene with the surrounding solvent/polymer environment.

Acknowledgements: This work was partially supported by NSF grant Nos. CHE-0074962, ECS-9876366, and ECS-0110381. Support of the Department of Education Graduate Assistantship in Areas of National Needs program (YKJ) is also acknowledged.

\section{References}

[1] F. Josse, F. Bender, R.W. Cernosek, "Guided Shear Horizontal Surface Acoustic Wave Sensors for Chemical and Biochemical Detection in Liquids," Anal. Chem. vol 73, pp. 5937-5944, 2001.

[2] J.W. Grate, "Solubility Interactions and the Design of Chemically Selective Sorbent Coatings for Chemical Sensor Arrays," Sensors and Actuators B, vol 3. pp. 85-111, 1991.

[3] R.A. McGill, "Choosing Polymer Coatings for Gas and Liquid Chemical Microsensors," SPE Society of Plastics Engineers Annual Technical Conference Proc., May 5-10, 1996, pp. 2080-2084, 1996.

[4] Z. Liron, N. Kaushansky, G. Frishman, D. Kaplan, J. Greenblatt, "The Polymer-coated SAW Sensor as a Gravimetric Sensor," Anal. Chem. vol. 69, pp. 2848-2854, 1997.

[5] J. W. Grate, A. Snow, D. S. Ballantine, Jr., H. Wohltjen, M. H. Abraham, R. A. McGill, P. Sasson, " Determination of Partition Coefficients from Surface Acoustic Wave Vapor Sensor Responses and Correlation with Gas-Liquid Partition Coefficients," Anal. Chem. Vol. 60, pp. 869-875

[6] A. Hierlemann, E. Zellers, A. Ricco, "Use of Linear Solvation Energy Relationships for modeling Responses from Polymer-Coated AcousticWave Vapor Sensors," Anal. Chem. Vol. 73, pp 3459-3466, 2001.

[7] R.A. McGill, M.H. Abraham, J.W. Grate, "Choosing polymer coatings for chemical sensors," CHEMTECH , vol 24, pp. 27-37, 1994.

[8] M. H. Abraham, J. Andonian-Haftvan, G. S. Whiting, A. Leo, "Hydrogen Bonding. Part 34. The factors that Influence the Solubility of Gasses and Vapors in Water at $298 \mathrm{~K}$, and a New Method for its Determination," J. Chem. Soc. Perkins Trans. 2, vol. 8, pp. 1777-1791, 1994.

[9] J. Workman, Jr., A. W. Springsteen, Applied Spectroscopy, San Diego, CA: Academic Press, (1998).

IEEE Sensors Journal, Vol. 5, No. 6 (December 2005): pg. 1175-1184. DOI. This article is ( Institute of Electrical and Electronics Engineers (IEEE) and permission has been granted for this version to appear in e-Publications@Marquette. Institute of Electrical and Electronics Engineers (IEEE) does not grant permission for this article to be further copied/distributed or hosted elsewhere without the express permission from Institute of Electrical and Electronics Engineers (IEEE). 
NOT THE PUBLISHED VERSION; this is the author's final, peer-reviewed manuscript. The published version may be

accessed by following the link in the citation at the bottom of the page.

[10] J. Grdadolnik, "An Attenuated Total Reflection Infrared Spectroscopy of Water Solutions," Int. J. Vibr. Spec., [www.ijvs.com] vol. 6, ed. 2, 2002.

[11] M. W. Urban, Attenuated Total Reflectance Spectroscopy of Polymers, Washington, DC: American Chemical Society (1996).

[12] I. Linossier, F. Gaillard, M. Romand, J.F. Polymer Films on the Substrate by Internal Reflection Fourier Transform Infrared Spectroscopy," J. Appl. Polymer Science, vol. 66. pp. 2465-2473, 1997

[13] J. Yang, Y. Huang, "IR Chemical Sensor for Detection of Aromatic Compounds in Aqueous Solutions using Alkylated Polystyrene-Coated ATR Waveguides" Applied Spectroscopy, vol. 54, pp. 202-208, 2000.

[14] J. Yang, M. Cheng, "Development of an SPME/ATR-IR chemical sensor for detection of phenol type compounds in aqueous solutions" Analyst, vol. 126, pp. 881-886, 2001.

[15] C. Sammon, C. Mura, J. Yarwood, N. Everall, R. Swart, D. Hodge, "FTIRATR Studies of the Structure and Dynamics of Water Molecules in Polymeric Matrixes," J. Phys. Chem. B, vol. 102, 3402-3411, 1998.

[16] M. Janotta, F. Vogt, H. Voraberger, W. Waldhauser, J. M. Lackner, C. Stotter, M. Beutl, B. Mizalkoff, "Direct Analysis of Oxidizing Agents in Aqueous Solution with Attenuated Total Reflectance Mid-Infrared Spectroscopy and Diamond-like Carbon Protected Waveguides," Anal. Chem., vol. 76, pp. 384-391, 2004.

[17] M. Janotta, K. Manfred, F. Vogt, B. Mizaikoff, "Sol-Gel Based Mid-infrared Evanescent Wave Sensors for Detection of Organophosphate Pesticides in Aqueous Solution", Analytica Chimica Acta, vol. 496, pp. 339-348, 2003.

[18] F. Vogt, M. Kraft, B. Mizaikoff, "First Results on Infrared Attenuated Total Reflection Spectroscopy for Quantitative Analysis of Salt Ions in Salt Water;" Applied Spectroscopy, vol. 56, pp.1376-1380, 2002.

[19] R.C. Thomas, A. Hierlemann, A.W. Staton, M. Hill, A.J. Ricco, "Reflectance Infrared Spectroscopy on Operating Surface Acoustic Wave Chemical Sensors" Anal. Chem., vol. 71, pp. 3615-3621, 1999.

[20] A.Hierlemann, A.J. Ricco, K. Bodenhöfer, W. Göpel, "Effective Use of Molecular Recognition in Gas Sensing: Results from Acoustic Wave and in Situ FT-IR Measurements" Anal. Chem., vol. 71, pp.3022-3035, 1999.

[21] N. J. Harrick, Internal Reflection Spectroscopy, NY: John Wiley and Sons (1979).

[22] J. Chen, J. A. Gardella, Jr., "Quantitative ATR FT-IR Analysis of Surface Segregation of Polymer Blends of Polystyrene/Poly(dimethylsiloxane)co-polystyrene," Appl. Spect., vol. 52, pp. 361-366, 1998.

[23] S.J. Clarson, J.A. Semlyen, Siloxane Polymers, New Jersey: Prentice Hall (1993).

IEEE Sensors Journal, Vol. 5, No. 6 (December 2005): pg. 1175-1184. DOI. This article is (C) Institute of Electrical and Electronics Engineers (IEEE) and permission has been granted for this version to appear in e-Publications@Marquette. Institute of Electrical and Electronics Engineers (IEEE) does not grant permission for this article to be further copied/distributed or hosted elsewhere without the express permission from Institute of Electrical and Electronics Engineers (IEEE). 
[24] J.M. Ziegler, F.W. Gordon Fearon, Silicon Based Polymer Science, Washington, DC: American Chemical Society (1990).

[25] Concentrations of saturated solutions were determined using data available from the EPA web site epa.gov.

[26] G. Sauerbrey, "The Use of Quartz Oscillators for Weighing Thin Layers and for Microweighing," Z. Phys., vol. 155, pp. 206-222, 1959.

[27] D. Gruner, P. Brumer, "Intramolecular Vibrational Redistribution in Alkylbenzenes. I. Normal Modes and Their Energy Redistribution," J. Chem. Phys., vol. 94, pp. 2848-2861, 1991.

[28] V.A. Shlyapochnikov, L.S. Khaikin, O.E. Grikina, C.W. Bock, L.V. Vilkov, "The Structure of Nitrobenzene and the Interpretation of the Vibrational Frequencies of the C-NO2 Moiety on the Basis of Ab Initio Calculations," J. Molec. Struct., vol 326, pp. 1-16, 1994.

[29] J.W. Grate, M. Klusty, R.A. McGill, M.H. Abraham, G. Whiting, J. Andonian-Haftvan, "The Predominant Role of Swelling-Induced Modulus Changes of the Sorbant Phase in Determining the Responses of Polymer-Coated Surface Acoustic Wave Vapor Sensors," Anal. Chem., vol. 64, pp. 610-624, 1992.

[30] S.J. Martin, G.C. Frye, S.D. Senturia, "Dynamics and Response of Polymer-Coated Surface Acoustic Wave Devices: The Effect of Viscoelastic Properties and Film Resonance," Anal. Chem., vol. 66, pp. 2201-2219, 1994.

[31] J. Kondoh, S. Shiokawa, M. Rapp, S. Stier, "Simulation of Viscoelastic Effects of Polymer Coatings on Surface Acoustic Wave Gas Sensor under Consideration of Film Thickness," Jpn. J. Appl. Phys., vol. 37, pp. 2842-2848 (1998).

[32] J.W. Grate, E.T. Zellers, "The Fractional Free Volume of the Sorbed Vapor in Modeling the Viscoelastic Contribution to Polymer-Coated Surface Acoustic Wave Vapor Sensor Response," Anal. Chem., vol. 72, pp. 2861-2868, 2000.

[33] J. W. Grate, S. N. Kaganove, V. R. Bhethanabotla, "Comparisons of Polymer/Gas Partition Coefficients Calculated from Responses of Thickness Shear Mode and Surface Acoustic Wave Vapor Sensors," Anal. Chem., vol. 70, pp. 199-203, 1998.

[34] A. Ahuja, D.L. James, R. Narayan, "Dynamic Behavior of Ultra-Thin Polymer Films Deposited on Surface Acoustic Wave Devices," Sensors Actuators, vol. 72, pp. 234-241, 1999.

[35] K. Bodenhöfer, A. Hierlemann, G. Noetzel, U. Wiemar, W. Göpel, "Performance of Mass-Sensitive Devices for Gas Sensing: Thickness Shear Mode and Surface Acoustic Wave Transducers," Anal. Chem., vol. 68, pp. 2210-2218, 1996.

IEEE Sensors Journal, Vol. 5, No. 6 (December 2005): pg. 1175-1184. DOI. This article is ( Institute of Electrical and Electronics Engineers (IEEE) and permission has been granted for this version to appear in e-Publications@Marquette. Institute of Electrical and Electronics Engineers (IEEE) does not grant permission for this article to be further copied/distributed or hosted elsewhere without the express permission from Institute of Electrical and Electronics Engineers (IEEE). 
[36] J. Reibel, S. Stier, A. Voigt, M. Rapp, "Influence of Phase Position on the Performance of Chemical Sensors Based on SAW Device Oscillators," Anal. Chem., vol. 70, pp. 5190-5197, 1998.

[37] S.J. Martin, G.C. Frye, "Surface Acoustic Wave Response to Changes in Viscoelastic Film Properties," Appl. Phys. Lett., vol. 57, pp. 1867-1869, 1990.

[38] J.-L. Rivail, D. Rinaldi, V. Dillet, "Solvent Effects in Infrared Spectroscopy: A Computational Approach," Molec. Phys., vol. 89, pp. 1521-1529, 1996.

[39] Gaussian 98W, M. J. Frisch, G. W. Trucks, H. B. Schlegel, G. E. Scuseria, M. A. Robb, J. R. Cheeseman, V. G. Zakrzewski, J. A. Montgomery, Jr., R. E. Stratmann, J. C. Burant, S. Dapprich, J. M. Millam, A. D. Daniels, K. N. Kudin, M. C. Strain, O. Farkas, J. Tomasi, V. Barone, M. Cossi, R. Cammi, B. Mennucci, C. Pomelli, C. Adamo, S. Clifford, J. Ochterski, G. A. Petersson, P. Y. Ayala, Q. Cui, K. Morokuma, D. K. Malick, A. D.

Rabuck, K. Raghavachari, J. B. Foresman, J. Cioslowski, J. V. Ortiz, A. G. Baboul, B. B. Stefanov, G. Liu, A. Liashenko, P. Piskorz, I. Komaromi, R. Gomperts, R. L. Martin, D. J. Fox, T. Keith, M. A. AlLaham, C. Y. Peng, A. Nanayakkara, C. Gonzalez, M. Challacombe, P. M. W. Gill, B. G. Johnson, W. Chen, M. W. Wong, J. L. Andres, M. Head-Gordon, E. S. Replogle and J. A. Pople, Gaussian, Inc., Pittsburgh PA, 1998.

[40] M. W. Wong, K. B. Wiberg and M. J. Frisch, "Solvent Effects 2. Medium Effect on the Structure, Energy, Charge Density, and Vibrational Frequencies of Sulfamic Acid," J. Amer. Chem. Soc. Vol. 114, pp. 523$529,1992$.

[41] A. D. Becke, "Density-functional thermochemistry. III. The role of exact exchange," J. Chem. Phys. vol. 98, pp. 5648-5652, 1993.

[42] M. J. Frisch, J. A. Pople and J. S. Binkley, "Self-Consistent Molecular Orbital Methods 25: Supplementary Functions for Gaussian Basis Sets," J. Chem. Phys. vol. 80, pp. 3265-3269, 1984.

[43] CRC Handbook of Chemistry and Physics, 69th Edition, Robert C. Weast, ed., Boca Raton, FL: CRC Press, Inc (1988-89).

[44] A.A. El-Azhary, H.U. Suter, "Comparison between Optimized Geometries and Vibrational Frequencies Calculated by the DFT Methods," J. Phys. Chem., vol. 100, pp. 15056-15063, 1996.

[45] J.J.P. Stewart, "Optimization of parameters for semiempirical methods. I. Method," J. Comp. Chem., vol. 10, pp. 209-220, 1989.

[46] N. A. Diachun, A. H. Marcus, D. M. Hussey, M. D. Fayer, "Dynamics in Polydimethylsiloxane: The Effect of Solute Polarity," J. Am. Chem. Soc., vol. 116, pp. 1027-1032, 1994.

IEEE Sensors Journal, Vol. 5, No. 6 (December 2005): pg. 1175-1184. DOI. This article is ( Institute of Electrical and Electronics Engineers (IEEE) and permission has been granted for this version to appear in e-Publications@Marquette. Institute of Electrical and Electronics Engineers (IEEE) does not grant permission for this article to be further copied/distributed or hosted elsewhere without the express permission from Institute of Electrical and Electronics Engineers (IEEE). 
NOT THE PUBLISHED VERSION; this is the author's final, peer-reviewed manuscript. The published version may be accessed by following the link in the citation at the bottom of the page.

[47] S.G. Charati, S.A. Stern, "Diffusion of Gases in Silicon Polymers: Molecular Dynamics Simulations," Macromol., vol. 31, 5529-5535, 1998.

Table 1. Polymer Partition Coefficients

\begin{tabular}{lllllll}
\hline \hline & $\begin{array}{l}\text { Poly- } \\
\text { (dimethylsiloxane) }\end{array}$ & $\begin{array}{l}\text { Poly- } \\
\text { (isobutylene) } \\
\text { PIB }\end{array}$ & $\begin{array}{l}\text { Poly- } \\
\text { (epichlorhydrin) } \\
\text { PECH }\end{array}$ \\
\cline { 2 - 7 } & $\mathrm{K}_{\mathrm{a} \rightarrow \mathrm{p}}$ & $\mathrm{K}_{\mathrm{w} \rightarrow \mathrm{p}}$ & $\mathrm{K}_{\mathrm{a} \rightarrow \mathrm{p}}$ & $\mathrm{K}_{\mathrm{w} \rightarrow \mathrm{p}}$ & $\mathrm{K}_{\mathrm{a} \rightarrow \mathrm{p}}$ & $\mathrm{K}_{\mathrm{w} \rightarrow \mathrm{p}}$ \\
Ethylbenzene & 3153 & 772 & 1672 & 464 & 2425 & 673 \\
Xylenes & 2785 & 743 & 2137 & 458 & 3284 & 700 \\
Toluene & 1164 & 279 & 583 & 140 & 1040 & 249 \\
Nitrobenzene & 526 & 1.5 & 256 & 0.75 & 3482 & 10 \\
\hline
\end{tabular}

Calculated from literature parameters $[6,7,8]$

Table 2 Nitrobenzene $\mathrm{NO}_{2}$ Asymmetric Stretching Mode Calculations

\begin{tabular}{cccccc}
\hline $\begin{array}{c}\text { Polymer/ } \\
\text { Solvent }\end{array}$ & $\begin{array}{c}\text { Experimental } \\
\left(\mathbf{c m}^{-1}\right)\end{array}$ & $\begin{array}{l}\text { Onsager } \\
\text { SCRF }\left(\mathbf{c m}^{-1}\right) \\
\text { unscaled }\end{array}$ & $\begin{array}{l}\text { Onsager } \\
\text { SCRF }\left(\mathbf{c m}^{-1}\right) \\
\text { scaled }\end{array}$ & $\begin{array}{l}\text { PM3 } \\
\left(\mathbf{c m}^{-1}\right) \\
\text { unscaled }\end{array}$ & $\begin{array}{l}\text { PM3 } \\
\left(\mathbf{c m}^{-1}\right) \\
\text { scaled }\end{array}$ \\
\hline Gas phase & $1548.60[28]$ & 1583.5 & 1552 & 1902 & 1541 \\
\hline Water & 1518 & 1555.1 & 1524 & 1874 & 1518 \\
PECH & 1523 & $N / A$ & $N / A$ & 1883 & 1525 \\
PDMS & 1532 & 1569.5 & 1538 & 1886 & 1528 \\
PIB & 1529 & $\mathrm{~N} / \mathrm{A}$ & $\mathrm{N} / \mathrm{A}$ & 1892 & 1533 \\
\hline
\end{tabular}

IEEE Sensors Journal, Vol. 5, No. 6 (December 2005): pg. 1175-1184. DOI. This article is @ Institute of Electrical and Electronics Engineers (IEEE) and permission has been granted for this version to appear in e-Publications@Marquette. Institute of Electrical and Electronics Engineers (IEEE) does not grant permission for this article to be further copied/distributed or hosted elsewhere without the express permission from Institute of Electrical and Electronics Engineers (IEEE). 
NOT THE PUBLISHED VERSION; this is the author's final, peer-reviewed manuscript. The published version may be accessed by following the link in the citation at the bottom of the page.
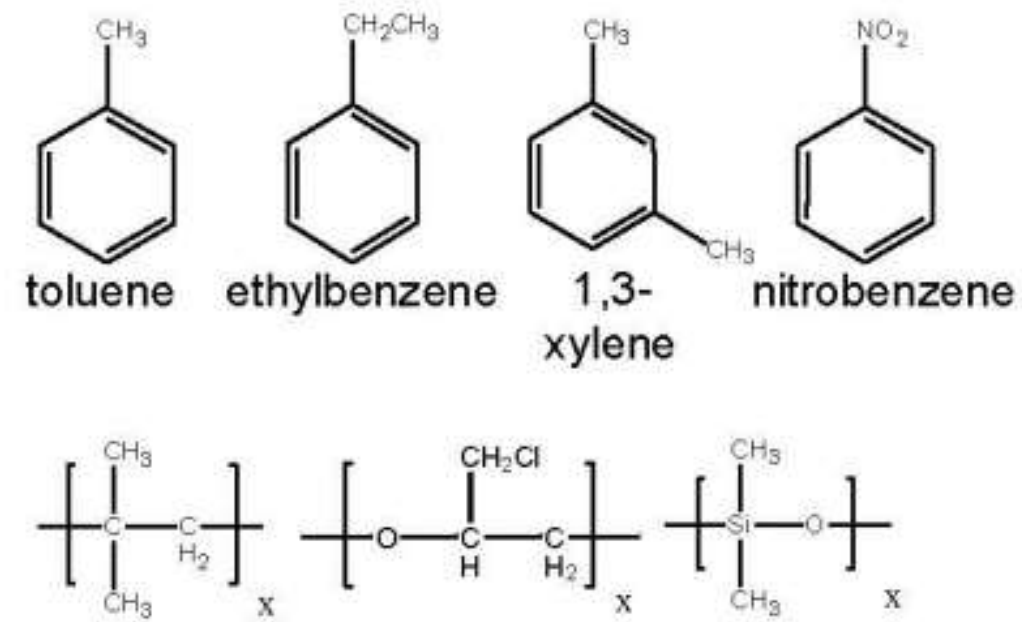

PIB

$\mathrm{PECH}$

PDMS

Figure 1. Structural formulas of analytes and polymer coatings.

IEEE Sensors Journal, Vol. 5, No. 6 (December 2005): pg. 1175-1184. DOI. This article is @ Institute of Electrical and Electronics Engineers (IEEE) and permission has been granted for this version to appear in e-Publications@Marquette. Institute of Electrical and Electronics Engineers (IEEE) does not grant permission for this article to be further copied/distributed or hosted elsewhere without the express permission from Institute of Electrical and Electronics Engineers (IEEE). 


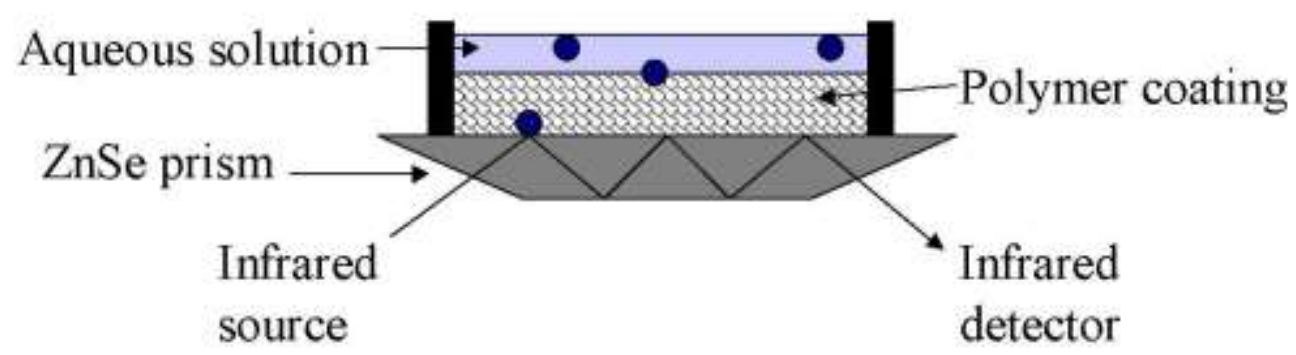

Figure 2. Schematic representation of a horizontal ATR accessory with a ZnSe prism surface coated with a polymer film and exposed to an aqueous analyte solution (analyte molecules are represented as solid circles). Note that only 3 internal reflections are shown for simplicity and that the penetration depth of the IR evanescent wave is significantly smaller than the thickness of the polymer coating.

IEEE Sensors Journal, Vol. 5, No. 6 (December 2005): pg. 1175-1184. DOI. This article is @ Institute of Electrical and Electronics Engineers (IEEE) and permission has been granted for this version to appear in e-Publications@Marquette. Institute of Electrical and Electronics Engineers (IEEE) does not grant permission for this article to be further copied/distributed or hosted elsewhere without the express permission from Institute of Electrical and Electronics Engineers (IEEE). 
NOT THE PUBLISHED VERSION; this is the author's final, peer-reviewed manuscript. The published version may be accessed by following the link in the citation at the bottom of the page.

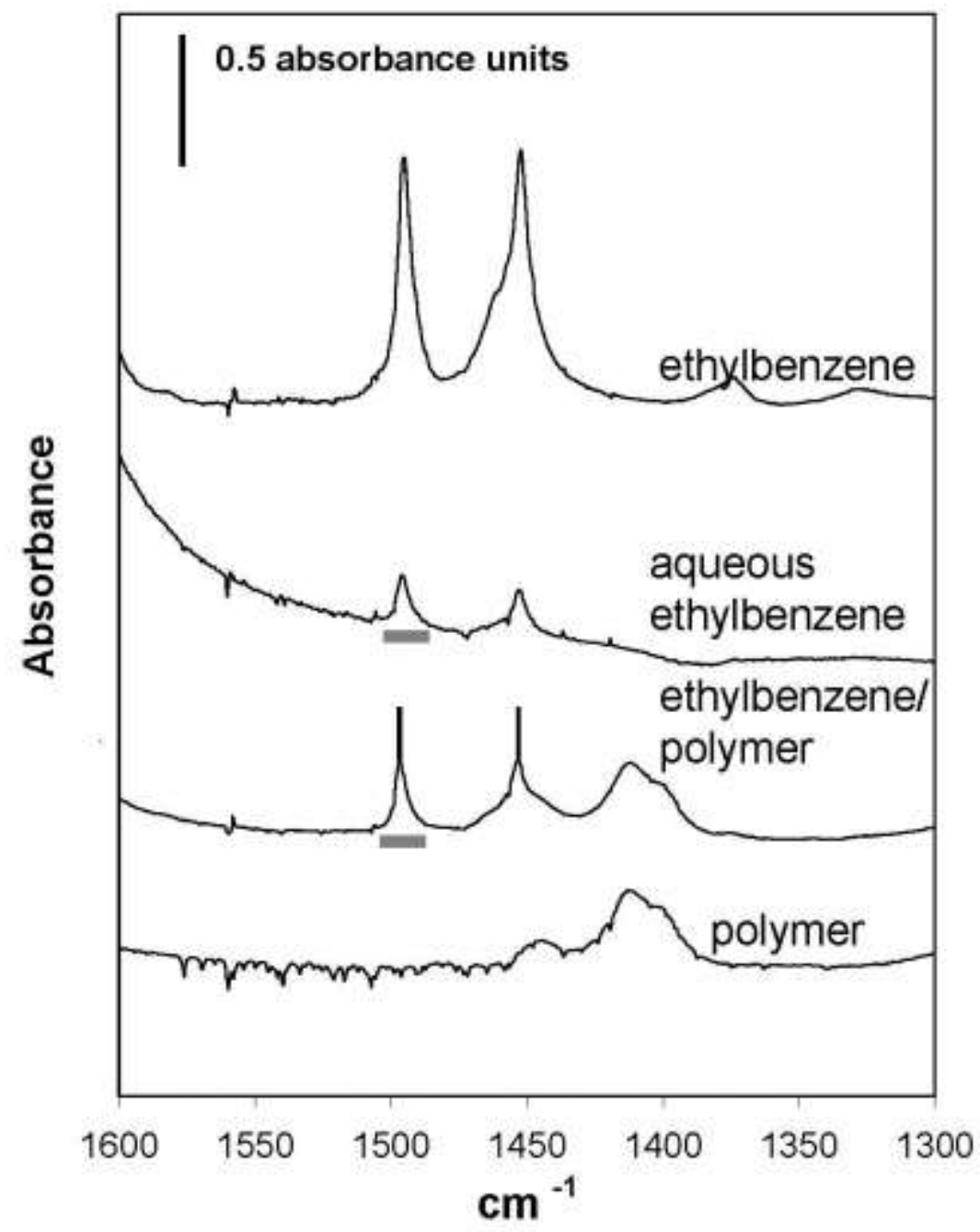

Figure 3. Selected portion of the infrared spectra of (from top to bottom): ethylbenzene, aqueous solution of ethylbenzene, aqueous ethylbenzene partitioned into the polymer, and the polymer coating. Spectra are offset for clarity but not otherwise normalized. The horizontal bars indicate the approximate region between $v_{\text {upper }}$ and $v_{\text {fower }}$ used in determining integrated intensities.

IEEE Sensors Journal, Vol. 5, No. 6 (December 2005): pg. 1175-1184. DOI. This article is @ Institute of Electrical and Electronics Engineers (IEEE) and permission has been granted for this version to appear in e-Publications@Marquette. Institute of Electrical and Electronics Engineers (IEEE) does not grant permission for this article to be further copied/distributed or hosted elsewhere without the express permission from Institute of Electrical and Electronics Engineers (IEEE). 


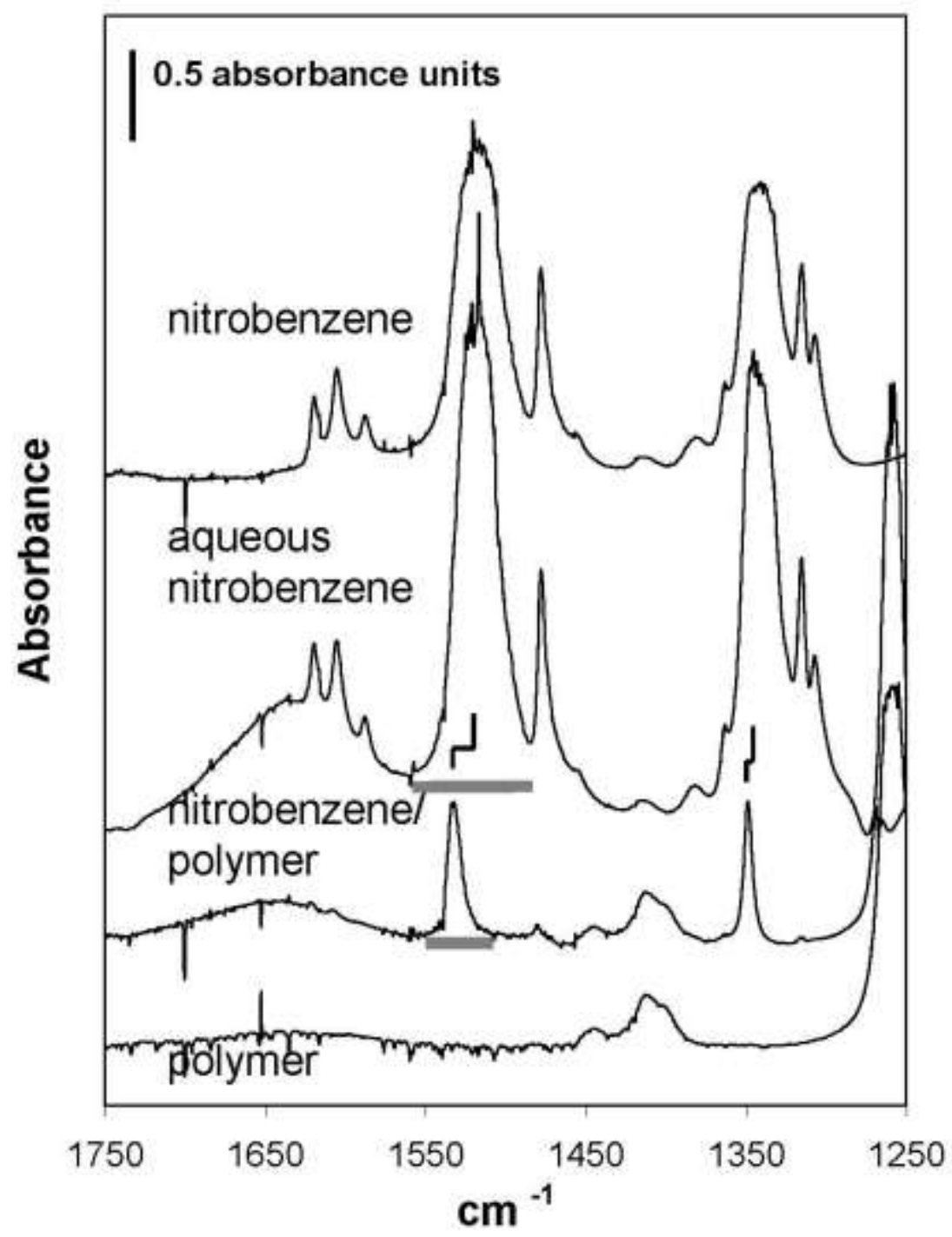

Figure 4. Selected portion of the infrared spectra of (from top to bottom): nitrobenzene, aqueous solution of nitrobenzene, aqueous nitrobenzene partitioned into the polymer, and the polymer coating. Spectra are offset but not otherwise normalized. The horizontal bars indicate the approximate region between $v_{\text {uppor }}$ and $v_{\text {lower }}$ used in determining integrated intensities.

IEEE Sensors Journal, Vol. 5, No. 6 (December 2005): pg. 1175-1184. DOI. This article is @ Institute of Electrical and Electronics Engineers (IEEE) and permission has been granted for this version to appear in e-Publications@Marquette. Institute of Electrical and Electronics Engineers (IEEE) does not grant permission for this article to be further copied/distributed or hosted elsewhere without the express permission from Institute of Electrical and Electronics Engineers (IEEE). 
NOT THE PUBLISHED VERSION; this is the author's final, peer-reviewed manuscript. The published version may be accessed by following the link in the citation at the bottom of the page.

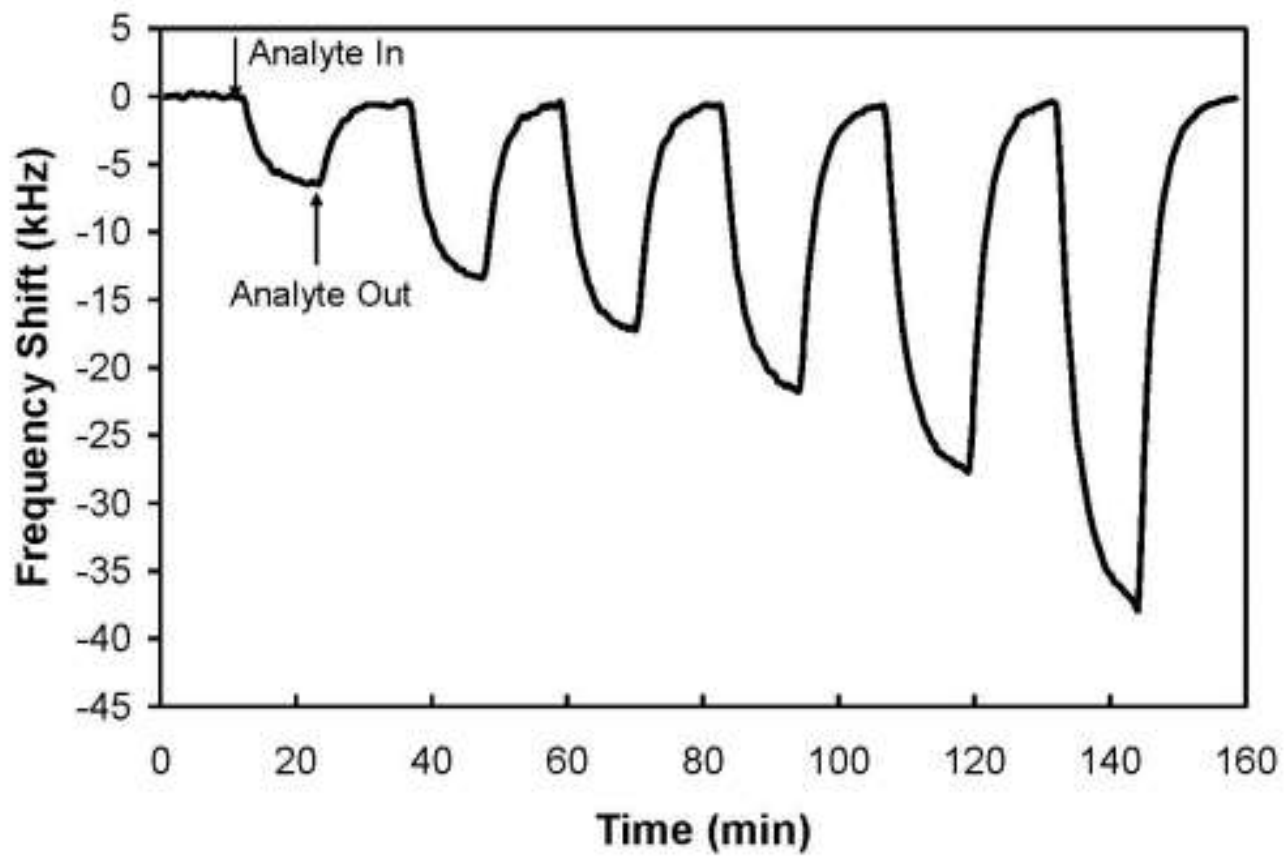

Figure 5. Frequency shifts of $0.8 \mu \mathrm{m}$ PIB coated guided SH-SAW sensor exposed to flowing solutions of $10-60 \mathrm{ppm}(-0.1 \mathrm{mM}-0 . \mathrm{m} 6 \mathrm{M})$ aqueous xylenes.

IEEE Sensors Journal, Vol. 5, No. 6 (December 2005): pg. 1175-1184. DOI. This article is @ Institute of Electrical and Electronics Engineers (IEEE) and permission has been granted for this version to appear in e-Publications@Marquette. Institute of Electrical and Electronics Engineers (IEEE) does not grant permission for this article to be further copied/distributed or hosted elsewhere without the express permission from Institute of Electrical and Electronics Engineers (IEEE). 
NOT THE PUBLISHED VERSION; this is the author's final, peer-reviewed manuscript. The published version may be accessed by following the link in the citation at the bottom of the page.

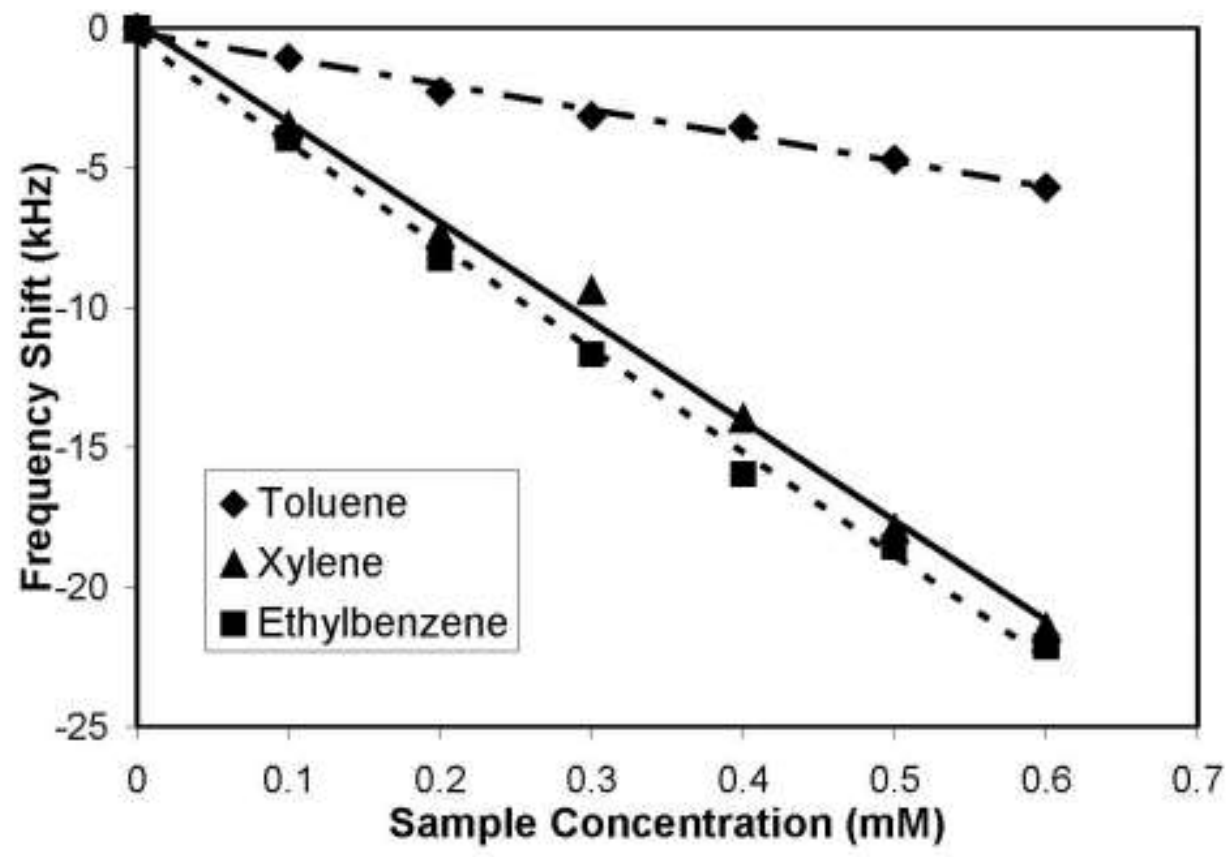

Figure 6. Baseline-corrected frequency shifts versus analyte concentration for a $0.8 \mu \mathrm{m}$ PIB coated guided SH-SAW exposed to ethylbenzene, xylenes, and toluene.

IEEE Sensors Journal, Vol. 5, No. 6 (December 2005): pg. 1175-1184. DOI. This article is @ Institute of Electrical and Electronics Engineers (IEEE) and permission has been granted for this version to appear in e-Publications@Marquette. Institute of Electrical and Electronics Engineers (IEEE) does not grant permission for this article to be further copied/distributed or hosted elsewhere without the express permission from Institute of Electrical and Electronics Engineers (IEEE). 
NOT THE PUBLISHED VERSION; this is the author's final, peer-reviewed manuscript. The published version may be accessed by following the link in the citation at the bottom of the page.

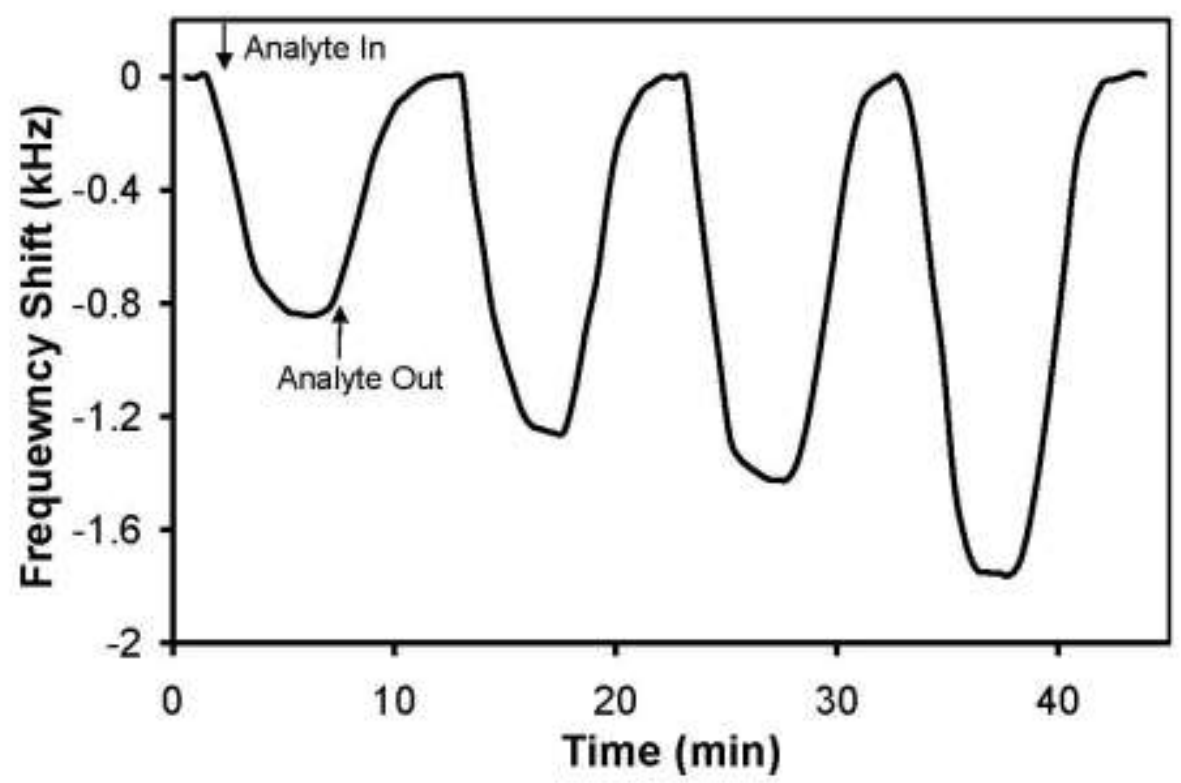

Figure 7. Frequency shifts observed for exposure of a $0.8 \mu \mathrm{m}$ PDMS-coated guided SH-SAW sensor to nitrobenzene.

IEEE Sensors Journal, Vol. 5, No. 6 (December 2005): pg. 1175-1184. DOI. This article is @ Institute of Electrical and Electronics Engineers (IEEE) and permission has been granted for this version to appear in e-Publications@Marquette. Institute of Electrical and Electronics Engineers (IEEE) does not grant permission for this article to be further copied/distributed or hosted elsewhere without the express permission from Institute of Electrical and Electronics Engineers (IEEE). 


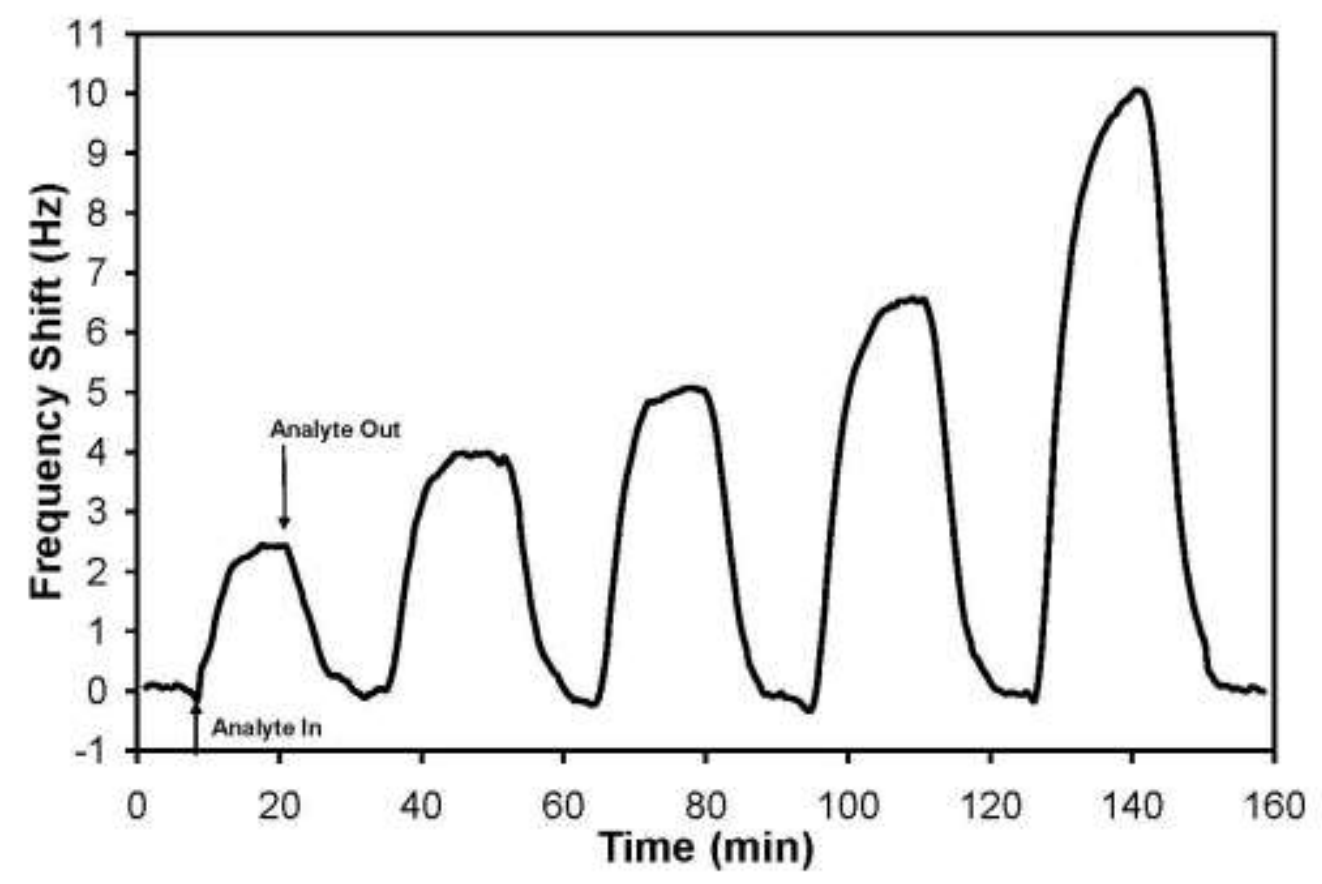

Figure 8. Frequency shifts observed for exposure of a $0.8 \mu \mathrm{m}$ PDMS-coated guided SH-SAW sensor to ethyl benzene.

IEEE Sensors Journal, Vol. 5, No. 6 (December 2005): pg. 1175-1184. DOI. This article is @ Institute of Electrical and Electronics Engineers (IEEE) and permission has been granted for this version to appear in e-Publications@Marquette. Institute of Electrical and Electronics Engineers (IEEE) does not grant permission for this article to be further copied/distributed or hosted elsewhere without the express permission from Institute of Electrical and Electronics Engineers (IEEE). 
NOT THE PUBLISHED VERSION; this is the author's final, peer-reviewed manuscript. The published version may be accessed by following the link in the citation at the bottom of the page.

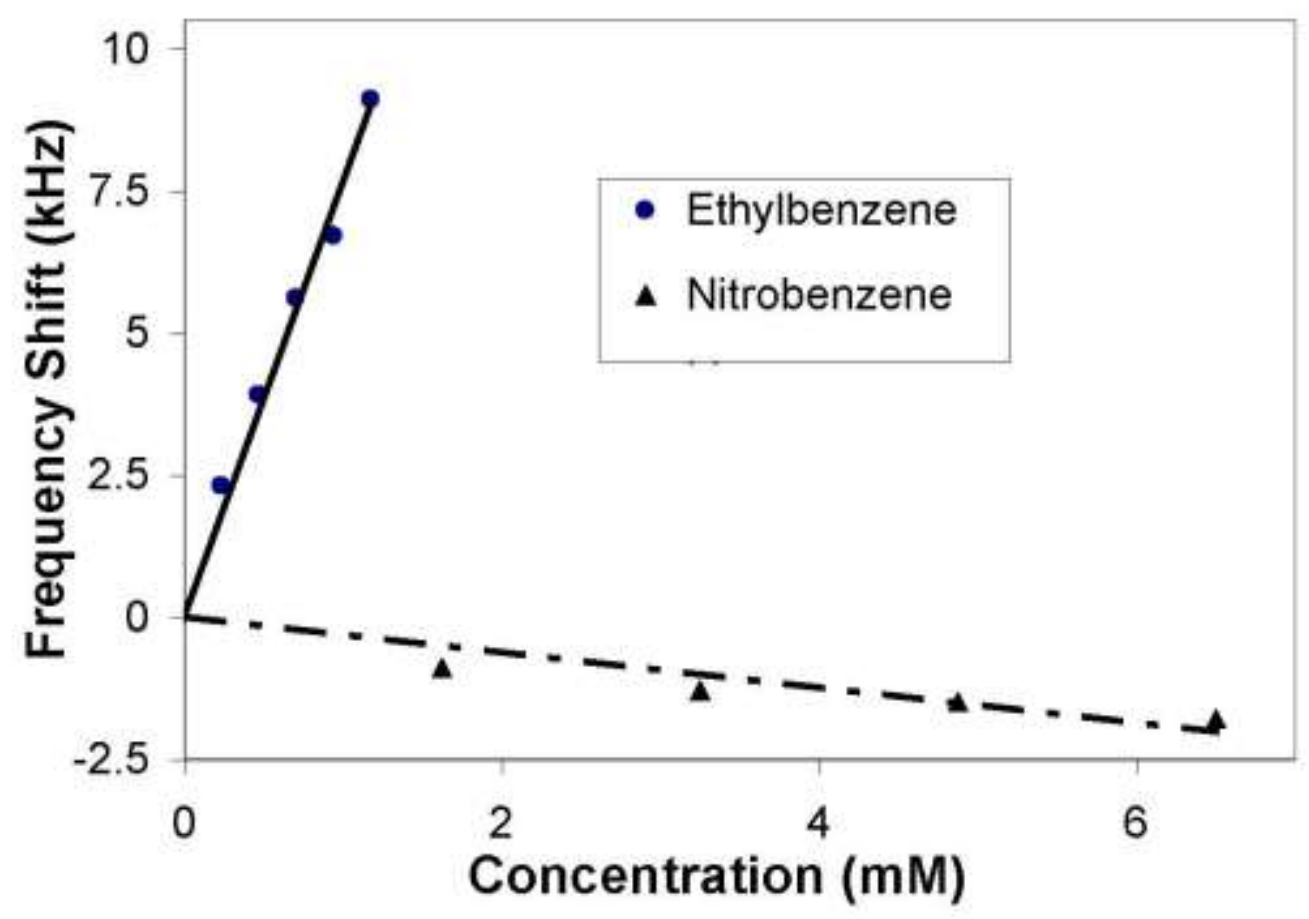

Figure 9. Baseline-corrected frequency shifts versus analyte concentrations for a guided SHSAW coated with PDMS exposed to flowing solutions: of 25-125 ppm (0.2-1 mM) ethylbenzene (circles) and to $200-800 \mathrm{ppm}(\mathrm{L} 6-6.3 \mathrm{mM})$ nitrobenzene (triangles).

IEEE Sensors Journal, Vol. 5, No. 6 (December 2005): pg. 1175-1184. DOI. This article is @ Institute of Electrical and Electronics Engineers (IEEE) and permission has been granted for this version to appear in e-Publications@Marquette. Institute of Electrical and Electronics Engineers (IEEE) does not grant permission for this article to be further copied/distributed or hosted elsewhere without the express permission from Institute of Electrical and Electronics Engineers (IEEE). 
NOT THE PUBLISHED VERSION; this is the author's final, peer-reviewed manuscript. The published version may be accessed by following the link in the citation at the bottom of the page.
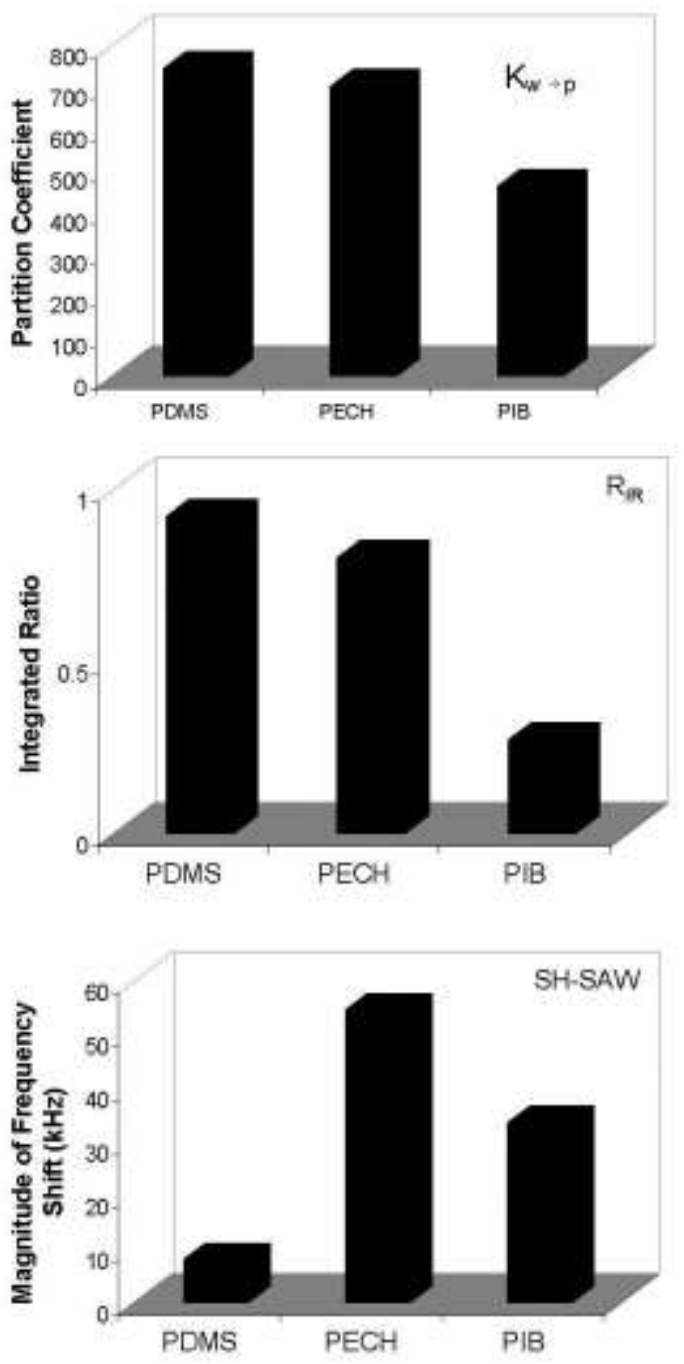

Figure 10. Comparison of coatings with respect to detection of xylenes. Values were not normalized.

IEEE Sensors Journal, Vol. 5, No. 6 (December 2005): pg. 1175-1184. DOI. This article is @ Institute of Electrical and Electronics Engineers (IEEE) and permission has been granted for this version to appear in e-Publications@Marquette. Institute of Electrical and Electronics Engineers (IEEE) does not grant permission for this article to be further copied/distributed or hosted elsewhere without the express permission from Institute of Electrical and Electronics Engineers (IEEE). 
NOT THE PUBLISHED VERSION; this is the author's final, peer-reviewed manuscript. The published version may be accessed by following the link in the citation at the bottom of the page.

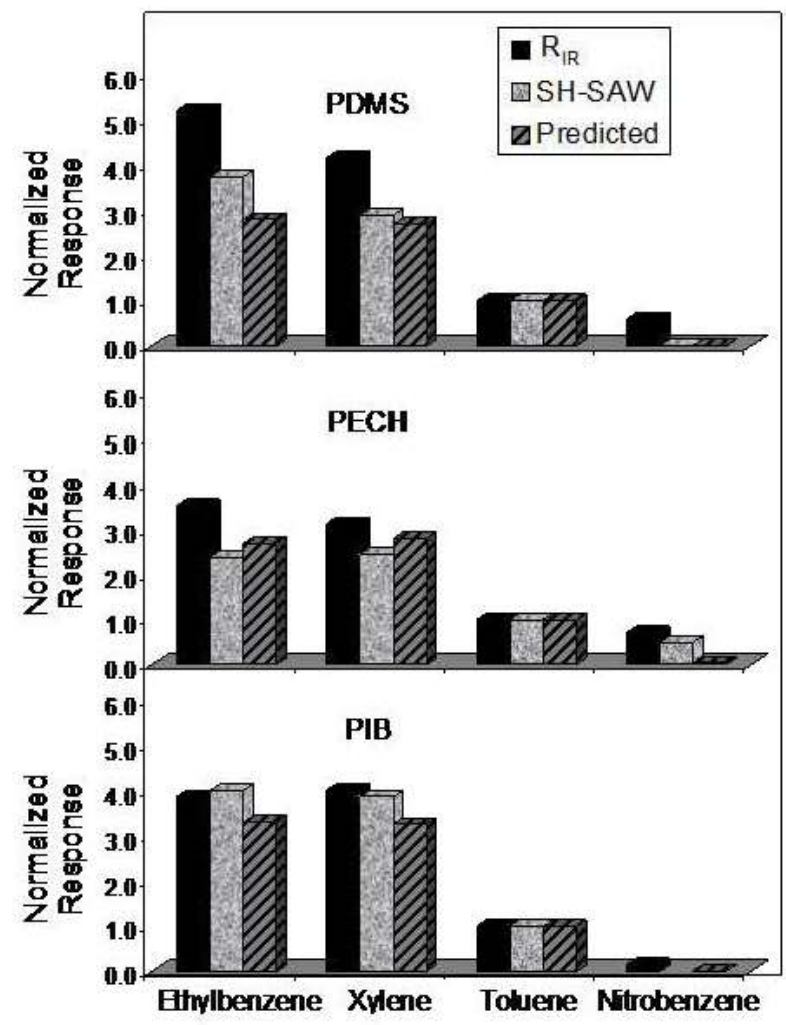

Figure 11. Response trends for ATR-FTIR RIR, absolute values of guided SH-SAW frequency shifts, and predicted partition coefficients for PDMS, PECH, and PIB exposed to four model analytes. All values for a given coating are normalized with respect to the corresponding value for toluene

IEEE Sensors Journal, Vol. 5, No. 6 (December 2005): pg. 1175-1184. DOI. This article is @ Institute of Electrical and Electronics Engineers (IEEE) and permission has been granted for this version to appear in e-Publications@Marquette. Institute of Electrical and Electronics Engineers (IEEE) does not grant permission for this article to be further copied/distributed or hosted elsewhere without the express permission from Institute of Electrical and Electronics Engineers (IEEE). 
NOT THE PUBLISHED VERSION; this is the author's final, peer-reviewed manuscript. The published version may be accessed by following the link in the citation at the bottom of the page.
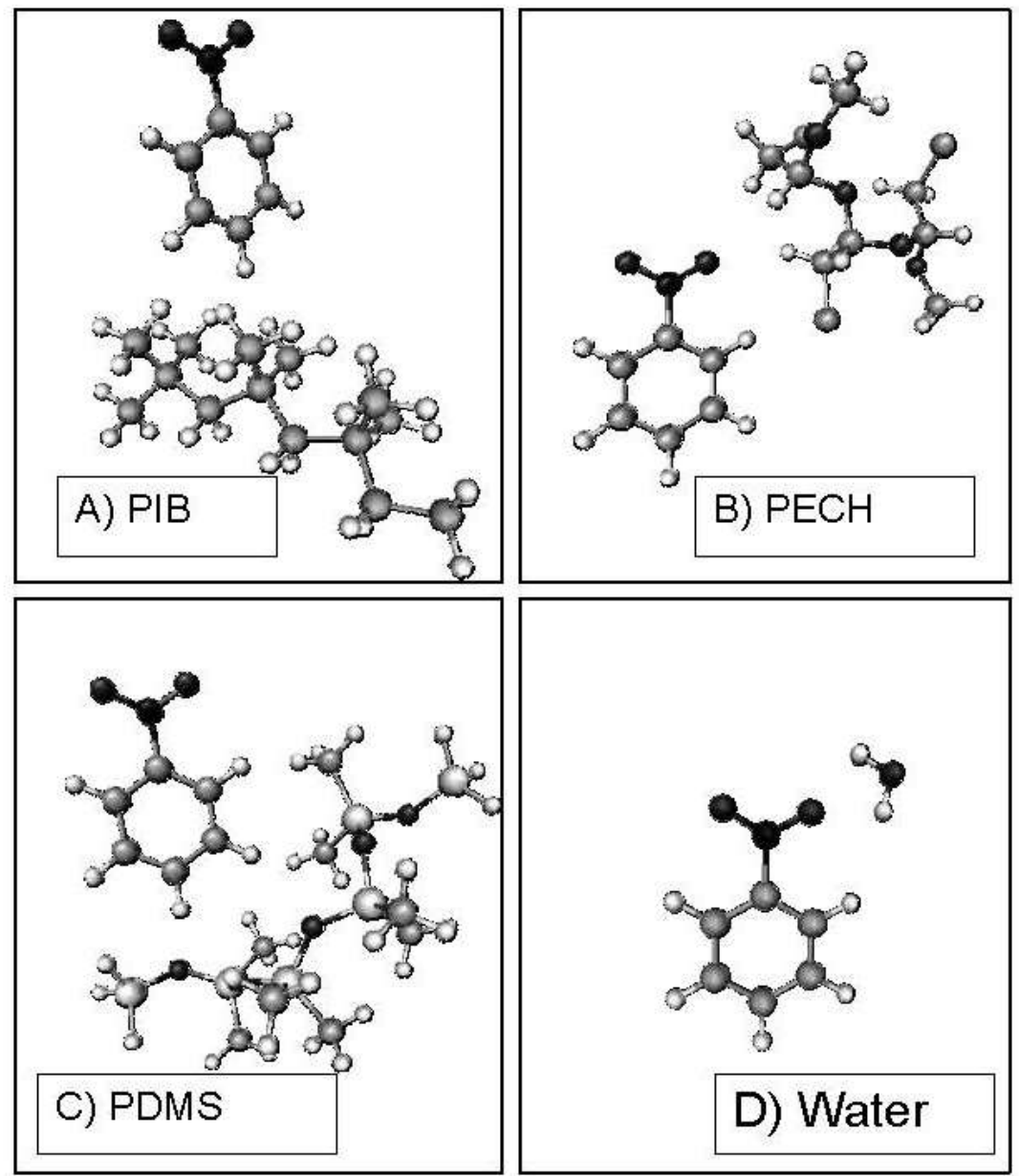

Figure 12. PM3 optimized structures of complexes of nitrobenzene with A) PIB, B) PECH, C)

PDMS, and D) water.

IEEE Sensors Journal, Vol. 5, No. 6 (December 2005): pg. 1175-1184. DOI. This article is (C) Institute of Electrical and Electronics Engineers (IEEE) and permission has been granted for this version to appear in e-Publications@Marquette. Institute of Electrical and Electronics Engineers (IEEE) does not grant permission for this article to be further copied/distributed or hosted elsewhere without the express permission from Institute of Electrical and Electronics Engineers (IEEE). 


\begin{tabular}{|l|l|}
\hline & $\begin{array}{l}\text { Yolanda K. Jones received a B.S. in chemistry from } \\
\text { Alcorn State University in Lorman, Mississippi. Yolanda } \\
\text { is currently pursuing a Ph.D. in physical chemistry at } \\
\text { Marquette University in Milwaukee, Wisconsin. The } \\
\text { current focus of her research is the study of } \\
\text { fundamental interactions of target environmental } \\
\text { toxins with polymer coatings for use in liquid sensor } \\
\text { applications. }\end{array}$ \\
\hline $\begin{array}{l}\text { Zhonghui Li received the B.S. degree in aircraft } \\
\text { design engineering and M.S. degree in automatic } \\
\text { instrumentation and apparatus from Northwestern } \\
\text { Polytechnical University, Xian, China in 1993 and } \\
\text { 1998, respectively. She joined the Ph.D. program in } \\
\text { electrical engineering, Marquette University, } \\
\text { Milwaukee, WI, in 2000 and expects to graduate in } \\
\text { May 2005. Her research focuses on the guided shear } \\
\text { horizontal surface acoustic wave devices and their } \\
\text { applications in (bio) chemical sensing. She is a } \\
\text { member of IEEE, IEEE-UFFC, Eta Kappa Nu and Tau } \\
\text { Beta Pi. }\end{array}$ \\
\hline
\end{tabular}

Michael M. Johnson received his B.S. and M.S. degrees in Electrical Engineering from Marquette University, Milwaukee, WI, in 2002 and 2004, respectively. His research area is in acoustic wave liquid-phase chemical sensors. His research interests also include the design of RF circuits for portable liquid-phase guided SH-SAW sensors.

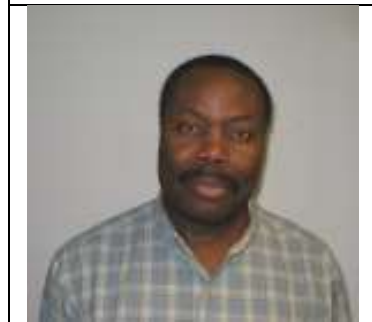

Fabien Josse received the License de Mathematics et Physique from the Université du Benin in 1976 and the M.S. and Ph.D. degrees in electrical engineering from the University of Maine at Orono in 1979 and 1982, respectively. He has been with Marquette University, Milwaukee, WI, since 1982 and is currently professor in the Department of Electrical and Computer Engineering, and the Department of Biomedical Engineering, as well as the Director of Graduates Studies. He is an adjunct professor in the Department of Electrical Engineering, Laboratory for Surface Science and Technology (LASST), University of Maine, and has been a visiting professor at the University of Heidelberg, Germany, since 1990, and a visiting professor at Laboratoire IXL, University of Bordeaux, France, and the Physical Electronics Laboratory (PEL) at the Swiss Federal Institute of Technology (ETH),

IEEE Sensors Journal, Vol. 5, No. 6 (December 2005): pg. 1175-1184. DOI. This article is @ Institute of Electrical and Electronics Engineers (IEEE) and permission has been granted for this version to appear in e-Publications@Marquette. Institute of Electrical and Electronics Engineers (IEEE) does not grant permission for this article to be further copied/distributed or hosted elsewhere without the express permission from Institute of Electrical and Electronics Engineers (IEEE). 


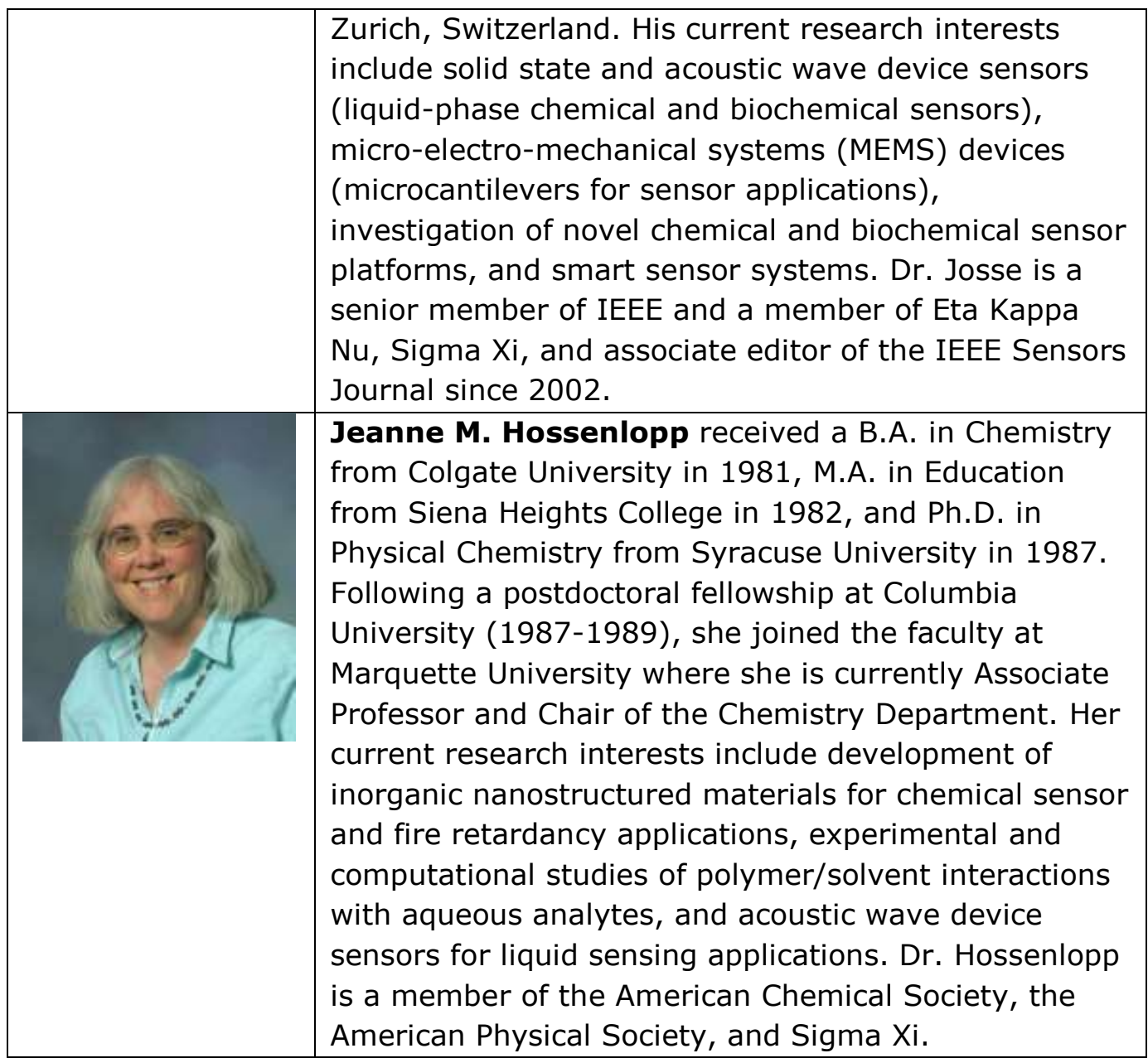

\section{Contact Information for Authors:}

\section{Yolanda K. Jones}

Marquette University

Department of Chemistry

P.O. Box 1881

Milwaukee, WI 53201-1881

Phone: (414) 288-2074

Fax: (414) 288-7066

Email: yolanda.jones@mu.edu

\section{Zhonghui Li}

Marquette University

Department of Electrical and Computer Engineering

P.O. Box 1881

Milwaukee, WI 53201-1881

IEEE Sensors Journal, Vol. 5, No. 6 (December 2005): pg. 1175-1184. DOI. This article is @ Institute of Electrical and Electronics Engineers (IEEE) and permission has been granted for this version to appear in e-Publications@Marquette. Institute of Electrical and Electronics Engineers (IEEE) does not grant permission for this article to be further copied/distributed or hosted elsewhere without the express permission from Institute of Electrical and Electronics Engineers (IEEE). 
NOT THE PUBLISHED VERSION; this is the author's final, peer-reviewed manuscript. The published version may be accessed by following the link in the citation at the bottom of the page.

Phone: (414) 288-7324

Fax: (414) 288-5579

Email: zhonghui.li@marquette.edu

\section{Michael Johnson}

Marquette University

Department of Electrical and Computer Engineering

P.O. Box 1881

Milwaukee, WI 53201-1881

Phone: (414) 288-7324

Fax: (414) 288-5579

Email: michael.d.johnson@mu.edu

\section{Fabien Josse}

Marquette University

Department of Electrical and Computer Engineering

P.O. Box 1881

Milwaukee, WI 53201-1881

Phone: (414) 288-6789

Fax: (414) 288-5579

Email: fabien.josse@mu.edu

\section{Jeanne M. Hossenlopp}

Marquette University

Department of Chemistry

P.O. Box 1881

Milwaukee, WI 53201-1881

Phone: (414) 288-3537

Fax: (414) 288-7066

Email: jeanne.hossenlopp@mu.edu 
NOT THE PUBLISHED VERSION; this is the author's final, peer-reviewed manuscript. The published version may be accessed by following the link in the citation at the bottom of the page.

IEEE Sensors Journal, Vol. 5, No. 6 (December 2005): pg. 1175-1184. DOI. This article is @ Institute of Electrical and Electronics Engineers (IEEE) and permission has been granted for this version to appear in e-Publications@Marquette. Institute of Electrical and Electronics Engineers (IEEE) does not grant permission for this article to be further copied/distributed or hosted elsewhere without the express permission from Institute of Electrical and Electronics Engineers (IEEE). 